\title{
Effects of Vitamin C on Organ Function in Cardiac Surgery Patients: A Systematic Review and Meta-Analysis
}

\author{
Aileen Hill 1,2,3,*, Kai C. Clasen 1,2,3, Sebastian Wendt ${ }^{2,3}$, Ádám G. Majoros 1,4, \\ Christian Stoppe ${ }^{1,3}$, Neill K. J. Adhikari ${ }^{5}$, Daren K. Heyland ${ }^{6}$ and Carina Benstoem ${ }^{1,3, *}$ \\ 1 Department of Intensive Care Medicine, Medical Faculty RWTH Aachen, D-52074 Aachen, Germany; \\ kaclasen@ukaachen.de (K.C.C.); adam.majoros@rwth-aachen.de (Á.G.M.); \\ christian.stoppe@googlemail.com (C.S.) \\ 2 Department of Anesthesiology, Medical Faculty RWTH Aachen, D-52074 Aachen, Germany; \\ wendt_s@gmx.net \\ 3 3CARE-Cardiovascular Critical Care and Anesthesia Evaluation and Research, D-52074 Aachen, Germany \\ 4 Medical Student of the Medical Faculty RWTH Aachen University, D-52074 Aachen, Germany \\ 5 Department of Critical Care Medicine, Sunnybrook Health Sciences Centre, Interdepartmental Division of \\ Critical Care Medicine, University of Toronto, Toronto, ON M4N 3M5, Canada; neill.adhikari@utoronto.ca \\ 6 Clinical Evaluation Research Unit, Kingston General Hospital, Kingston, CA K7L 2V7, Canada; \\ dkh2@queensu.ca \\ * Correspondence: ahill@ukaachen.de (A.H.); cbenstoem@ukaachen.de (C.B.); Tel.: +49-241-8038166 (A.H.); \\ $+49-241-8038038$ (C.B.)
}

Received: 29 June 2019; Accepted: 29 August 2019; Published: 4 September 2019

check for updates

\begin{abstract}
Background: Cardiac surgery is associated with oxidative stress and systemic inflammation, which both contribute to postoperative organ dysfunction. Vitamin C is a pleiotropic, antioxidant, and potentially organ-protective micronutrient. Past clinical trials and meta-analyses have focused predominantly on the occurrence of postoperative atrial fibrillation. Therefore, we investigated the influence of perioperative vitamin $C$ administration on clinically relevant parameters closer related to the patient's recovery, especially organ function, and overall outcomes after cardiac surgery. Methods: Randomized controlled trials (RCTs) comparing perioperative vitamin C administration versus placebo or standard of care in adult patients undergoing cardiac surgery were identified through systematic searches in Pubmed, Embase $®$, and the Cochrane Central Register of Controlled Trials of the Cochrane Library (CENTRAL) on 23 November 2018. Published and unpublished data were included. Assessed outcomes include organ function after cardiac surgery, adverse events, in-hospital mortality, intensive care unit, and hospital length of stay. Data were pooled only when appropriate. Results: A total of 19 RCTs with 2008 patients were included in this meta-analysis. Vitamin C significantly decreased the incidence of atrial fibrillation $(p<0.0001)$, ventilation time $(p=0.0003)$, intensive care unit (ICU) length-of-stay $(p=0.002)$, and hospital length of stay $(p=0.03)$. However, on average, vitamin $C$ had no significant effects on in hospital mortality ( $p=0.59)$, or on the incidence of stroke $(p=0.32)$. High statistical heterogeneity was observed in most analyses. Conclusions: Vitamin C impacts clinically and economically important outcomes, such as ICU and hospital length-of-stay, duration of mechanical ventilation, and lowers the incidence of atrial fibrillation. Due to missing reports on organ dysfunction, this meta-analysis cannot answer the question, if vitamin $C$ can improve single- or multi-organ function after cardiac surgery.
\end{abstract}

Keywords: cardiac surgery; oxidative stress; reperfusion injury; antioxidant; vitamin; ascorbic acid; organ dysfunction; systematic review; meta-analysis 


\section{Introduction}

Cardiac surgery triggers the release of inflammatory mediators and the production of reactive oxygen species, which lead to a systemic inflammatory response as well as oxidative stress $[1,2]$. The resulting disturbances in homeostasis contribute to the development of postoperative organ dysfunctions, which significantly determine the mid- to long-term outcome of the patients. In the past, several strategies have been developed to modulate and reduce the inflammatory responses, such as less invasive surgical techniques, leukocyte filters during cardiopulmonary bypass, and the use of immune-modulating drugs [3]. Despite these improvements, acute and persistent organ dysfunctions still occur frequently after cardiac surgery and consequently affect the patient's outcome and quality of life $[4,5]$.

Vitamin $C$ is an essential and pleiotropic micronutrient that is involved in numerous processes in the human body. Vitamin $C$ is a strong antioxidant, thereby countering the influence of free radicals and protecting the cells and organs from damage to macromolecules, such as cell membranes and DNA. Other crucial functions are vasopressor synthesis, restoration of vasopressor sensitivity, synthesis of collagen and carnitine, preservation of endothelial barriers and modulation of immune function $[4,6-10]$.

A perioperative antioxidant treatment with vitamin $C$ in patients undergoing cardiac surgery has been the subject of investigation in several clinical trials and has consequently been analyzed in following meta-analyses. Surprisingly, most of them have focused predominantly on the occurrence of atrial fibrillation [11-15]. However, despite the clinical significance of postoperative arrhythmia, the effects of vitamin $C$ on the patient's organ functions and long-term outcomes remain largely unknown.

Therefore, we aimed to investigate the influence of vitamin $C$ administration on clinically relevant parameters that are closer related to the patient's recovery, especially organ function, and overall outcomes after cardiac surgery

\section{Methods}

This systematic review was registered at the PROSPERO international database under the registration number CRD42018115340. This systematic review was performed according to Cochrane Standard, the reporting will be in line with the PRISMA (Preferred Reporting Items for Systematic Reviews and Meta-Analyses) statement.

\subsection{Search Strategy}

We included randomized controlled trials (RCTs) comparing perioperative vitamin C administration versus placebo or standard of care in adult patients undergoing cardiac surgery. Relevant trials were identified through systematic searches of the databases PubMed, Embase®, and the Cochrane Central Register of Controlled Trials of the Cochrane Library (CENTRAL) on 23 November 2018. All publications published until November 2018 in at least one of these databases were included. The systematic search included the terms "cardi*", "heart", "endocard", "myocard", "pericard", "coronar" ", "aort", "bypass", "valv*", "vitamin c", "vit c", "ascorb*" and "surg*", "procedure", "operation", "intervention" to be found in title or abstract. The following restrictions were made: "clinical study", "clinical trial", "RCT", "review", "Cochrane Review", "Systematic Review", "Meta Analysis", "Controlled Clinical Trial", "Randomized Controlled Trial" in the search masks of the according databases.

\subsection{Study Selection Criteria}

Studies were selected for inclusion in the review process if they met the following criteria:

- Study design: RCTs or meta-analysis of RCTs. Meta-analyses were reviewed for cross-referencing. When treatment allocation was not truly random, such as assigning a treatment intervention based on day of admission or month of service (pseudo-randomized trials), these trials were excluded. 
- Population: Adult patients undergoing open heart surgery (with or without cardiopulmonary bypass)

- Intervention: Any form of perioperative vitamin $C$ administration, defined by at least 1 day before, until 7 days after cardiac surgery. Studies with co-administration of other pharmacologic substances including pharmaconutrients and antioxidants were excluded, except for trials using the clinical standard treatment "B-blockers" in both groups (see below).

- Outcomes included in our meta-analysis: Incidence of organ dysfunction, adverse events, intensive care unit (ICU), and hospital length of stay (LOS), hospital discharge location, and mortality

We included published and unpublished data. Reporting one or more of these outcomes in the trial was not an inclusion criterion for the review. Where a published trial did not report one of these outcomes, we accessed the trial protocol (if available) and contacted the trial authors to ascertain whether the outcomes were measured but not reported. We included relevant trials, which measured these outcomes but did not report the data at all, or not in a usable format, as part of the narrative.

After thorough discussion between all authors, it was decided to allow RCTs also administrating B-blockers to the patients in both groups, as studies not using B-blocker as co-intervention also reported high percentages of their patients receiving perioperative ß-blocker therapy. However, this complicates the interpretation of outcomes, especially regarding hemodynamics and perioperative arrhythmia. On the other hand, ß-blockers are the clinical standard and including these patients in our meta-analysis will allow for easier translation into clinical practice.

\subsection{Selection of Studies and Data Extraction}

Of the identified potential studies, a database was constructed using the reference manager EndNote X9 (Clarivate Analytics, Boston, MA, USA). After identification and removal of duplicates, the titles and abstracts of the remaining studies were screened by two independent reviewers (AGM and KCC). Relevant full texts were retrieved and screened independently by two reviewers as well (AH and AGM) to select studies for inclusion, as well as to document reasons for exclusion of the ineligible studies. If there were any disagreements, a third author was asked to arbitrate (AH for abstract screening, KCC for full text screening). After abstract screening, authors of the selected studies were contacted for missing information. If essential information for the inclusion of the study was missing, the study was excluded. Full-texts published in a language other than English were translated or excluded if the full text could not be obtained (see Appendix A for manuscripts excluded from this analysis after full text screening). Multiple reports of the same study were collated so that each study, rather than each report, is the unit of interest in the review.

\subsection{Assessment of Risk of Bias in Included Studies}

Two authors (AH, CB) independently assessed risk of bias for each study using the criteria outlined in the Cochrane Handbook for Systematic Reviews of Interventions [16]. Disagreements were solved by discussion. The results of the "risk of bias"-assessment were summarized in both a "risk of bias" summary and a "risk of bias" graph. Seven "risk of bias"-domains (random sequence generation (checking for possible selection bias); blinding of participants and personnel (checking for possible performance bias); blinding of outcome assessment (checking for possible detection bias); allocation concealment (checking for possible selection bias); incomplete outcome data (checking for possible attrition bias through withdrawals, dropouts, protocol deviations); selective reporting (checking for reporting bias); and other bias (checking for other biases)) were identified and assessed as recommended in the Cochrane Handbook of Interventions [16], see Appendix B for more detail. 


\subsection{Measures of Treatment Effect}

Dichotomous data were analyzed as risk ratios (RR) with 95\% confidence intervals (CI). For continuous data, mean difference (MD) with $95 \%$ CI for outcomes measured in the same way between trials were used as implemented in RevMan 5 (Reference Manager 5, Version 5.3, Nordic Cochrane Centre, The Cochrane Collaboration, 2014, Copenhagen, Denmark).

Investigators were contacted to verify key study characteristics and to obtain missing numerical outcome data where possible (e.g., when a study was identified as an abstract only). Analyses were carried out on an intention-to-treat basis for all outcomes, as far as possible. Statistical analysis was performed using RevMan 5. Meta-analyses were undertaken only where this was meaningful, that is, if the treatments, participants and the underlying clinical questions were similar enough for pooling to make sense. Given the clinical heterogeneity regarding our inclusion criteria (different types of open-heart surgery, different types of vitamin $C$ administration) random-effects meta-analyses were used to produce an overall summary of average treatment effect across trials. The random-effects summary was treated as the average range of possible treatment effects and the clinical implications of treatment effects differing between trials were discussed. Results are presented as the average treatment effect with its $95 \%$ confidence interval, and the estimates of $\mathrm{Tau}^{2}$ and $\mathrm{I}^{2}$.

\subsection{Assessment of Statistical Heterogeneity}

Where data were pooled using meta-analysis, the presence of heterogeneity was assessed by visual inspection of forest plots and by examining the Chi ${ }^{2}$ test [17]. Statistical heterogeneity was assessed in each meta-analysis using the $\mathrm{Tau}^{2}, \mathrm{I}^{2}$ and $\mathrm{Chi}^{2}$ statistics [18]. Heterogeneity was regarded as substantial if:

1. The $\mathrm{I}^{2}$ value was high (exceeding $30 \%$ ); and either:

2. There was inconsistency between trials in the direction or magnitude of effects (judged visually), or there was a low $p$ value $(<0.10)$ in the $\mathrm{Chi}^{2}$ test for heterogeneity; or

3. The estimate of between-study heterogeneity $\left(\mathrm{Tau}^{2}\right)$ was above zero.

\section{Results}

\subsection{Study Selection Process}

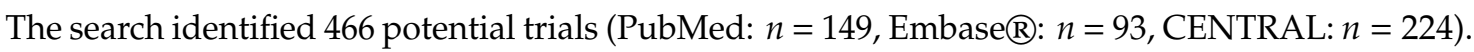
Nine additional articles were found during cross-referencing and from the authors own reference collections. After the removal of 146 duplicates, 329 RCTs underwent title and abstract screening, 47 trials underwent full-text screening. Reasons for exclusion after full text screening are provided in Appendix A. Nineteen trials were included in this analysis and underwent data extraction. The study selection process is shown in Figure 1. 


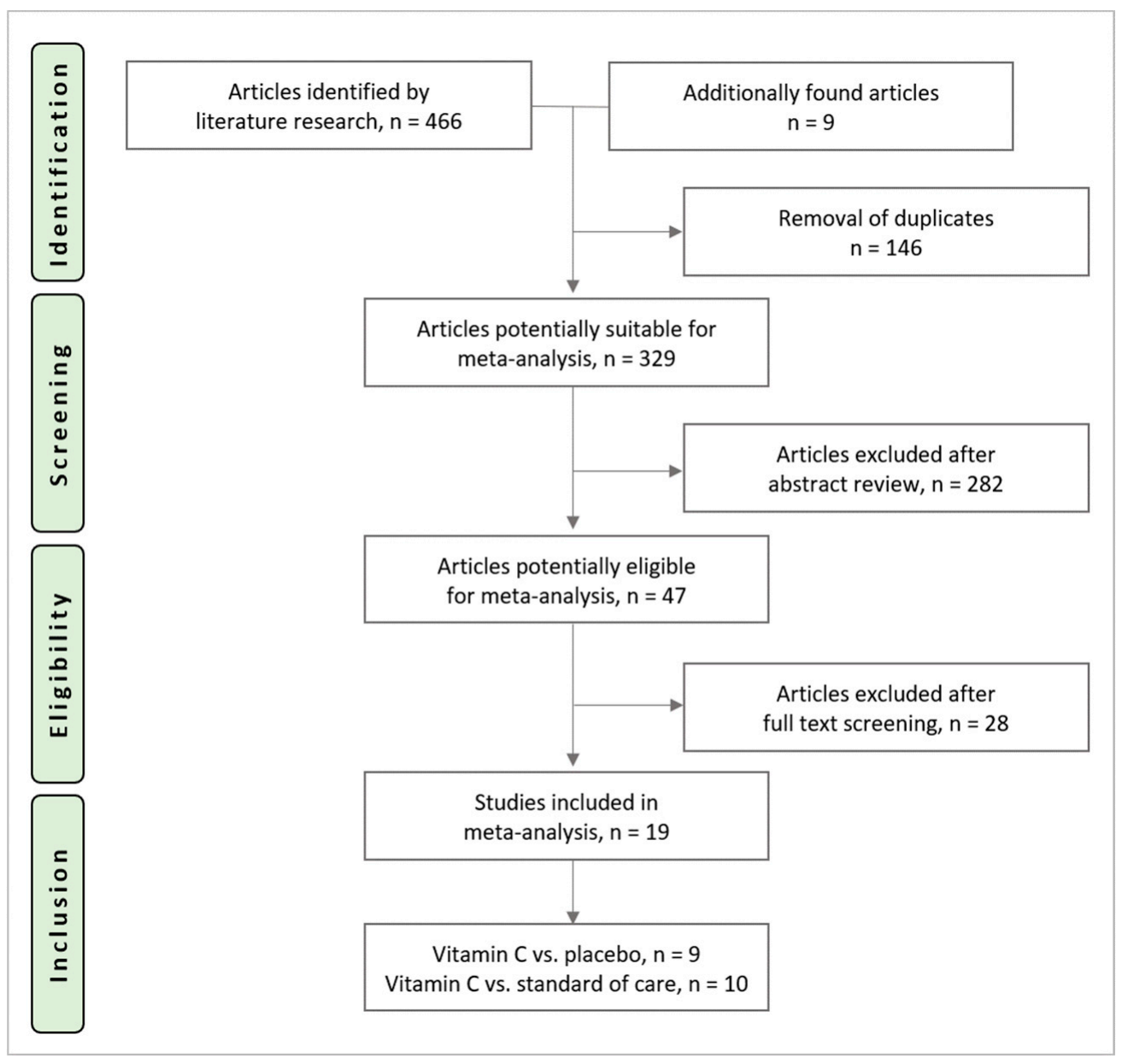

Figure 1. Study selection process.

\subsection{Characteristics of Included Studies}

Nineteen RCTs with 2008 patients were included. Their characteristics are described in Table 1. Nine trials including 1422 patients compared vitamin $C$ to a placebo and 10 trials including 932 patients were controlled by standard of care. Eight studies including 724 patients administered the study medication intravenously and six studies including 734 patients administered orally. One study with 290 patients supplemented intravenously before and orally after surgery [19]. In four trials, the mode of administration was not available [20-23]. 
Table 1. Characteristics of included studies, $\mathrm{CABG}=$ coronary artery bypass graft, $\mathrm{CPB}=$ cardiopulmonary bypass, Vit $\mathrm{C}=\mathrm{Vitamin} \mathrm{C}$, i.v. $=$ intravenously, p.o. $=$ orally, preop $=$ before surgery, postop $=$ after surgery, n.a. $=$ not available.

\begin{tabular}{|c|c|c|c|c|c|}
\hline & Author and Year & Patients & Dosage and Timing of Vitamin $\mathrm{C}$ in the Intervention Group & Route & Control Group \\
\hline 1 & Alshafey 2017 [20] & 100 scheduled CABG & Preop: $2 \mathrm{~g}$ daily for at least 3 days pre-operatively & n.a. & Standard of care \\
\hline 2 & Antonic 2016 [24] & 105 elective CABG with CPB & $\begin{array}{l}\text { Preop: } 2 \times 2 \mathrm{~g}: 24 \text { and } 2 \mathrm{~h} \text { before surgery } \\
\text { Postop: } 2 \times 1 \mathrm{~g} / \text { day for } 5 \text { days }\end{array}$ & i.v. & Standard of care \\
\hline 3 & Antonic 2017 [25] & 100 elective CABG with CPB & $\begin{array}{l}\text { Preop: } 2 \times 2 \mathrm{~g}: 24 \text { and } 2 \mathrm{~h} \\
\text { Postop: } 2 \times 1 \mathrm{~g} / \text { day for } 5 \text { days }\end{array}$ & i.v. & Standard of care \\
\hline 4 & Bakr 2015 [21] & 200 CABG & Preop: at least one week, dosage and route not specified & n.a. & Standard of care \\
\hline 5 & Bjordahl $2012[26]$ & 185 scheduled CABG & $\begin{array}{l}\text { Preop: } 1 \times 2 \mathrm{~g} \text { night before surgery } \\
\text { Postop: } 2 \times 1 \mathrm{~g} / \text { day for } 5 \text { days }\end{array}$ & p.o. & Placebo \\
\hline 6 & Colby 2011 [27] & 24 scheduled CABG and/or valvular surgery & $\begin{array}{l}\text { Preop: } 1 \times 2 \mathrm{~g} \text { night before } \\
\text { Postop: } 2 \times 0.5 \mathrm{~g} / \text { day for } 4 \text { days }\end{array}$ & p.o. & Placebo \\
\hline 7 & Dehghani 2014 [28] & 100 elective isolated CABG with $\mathrm{CPB}$ & $\begin{array}{l}\text { Preop: } 1 \times 2 \mathrm{~g} \text { before the surgery } \\
\text { Postop: } 2 \times 0.5 \mathrm{~g} / \text { day for } 5 \text { days }\end{array}$ & p.o. & Standard of care \\
\hline 8 & Demirag $2001[29]$ & 30 elective CABG & Group 1: $2 \times 50 \mathrm{mg} / \mathrm{kg}$ vitamin $\mathrm{C}$ after induction and before declamping & i.v. & Standard of care \\
\hline 9 & Donovan 2012 [30] & 150 & $\begin{array}{l}\text { Preop: } 2 \mathrm{~g} \text { the morning before surgery } \\
\text { Postop: } 2 \times 1 \mathrm{~g} \text { for } 5 \text { days }\end{array}$ & p.o. & Standard of care \\
\hline 10 & Eslami 2007 [31] & $\begin{array}{l}100 \text { elective isolated CABG patients with } \\
\text { CPB }\end{array}$ & $\begin{array}{l}\text { Preop: } 2 \mathrm{~g} \text { the night before surgery } \\
\text { Postop: } 2 \times 1 \mathrm{~g} \text { for } 5 \text { days }\end{array}$ & p.o. & Standard of care \\
\hline 11 & Healy 2010 [22] & 60 CABG and/or valve in interim analysis & n.a. & n.a. & Standard of care \\
\hline 12 & Jouybar 2012 [32] & 40 elective CABG & Preop: $2 \times 3 \mathrm{~g} 12-18 \mathrm{~h}$ before surgery and after induction of anesthesia & i.v. & Placebo \\
\hline 13 & Knodell 1981 [33] & 175 elective cardiac surgery & $\begin{array}{l}\text { Preop: } 4 \times 800 \mathrm{mg} / \text { day for } 2 \text { days } \\
\text { Postop: } 4 \times 800 \mathrm{mg} / \text { day for } 2 \text { weeks, started } \\
\text { as soon as patient could take oral liquids }\end{array}$ & p.o. & Placebo \\
\hline 14 & Papoulidis 2011 [34] & 170 elective isolated $\mathrm{CABG}$ with $\mathrm{CPB}$ & $\begin{array}{l}\text { Preop: } 1 \times 2 \mathrm{~g} 3 \mathrm{~h} \text { prior to initiation of CPB } \\
\text { Postop: } 2 \times 0.5 \mathrm{mg} / \text { day for } 5 \text { days }\end{array}$ & i.v. & Placebo \\
\hline 15 & Polymeropoulos 2015 [35] & 22 cardiac surgery with $\mathrm{CPB}$ & $\begin{array}{l}\text { Preop: } 4 \times 500 \mathrm{mg} / \mathrm{d} \text { for } 2 \text { days prior to surgery } \\
\text { Postop: } 4 \times 500 \mathrm{mg} / \mathrm{d} \text { for } 4 \text { days }\end{array}$ & i.v. & Placebo \\
\hline 16 & Sadeghpour 2015 [19] & 290 elective CABG or valve & $\begin{array}{l}\text { Preop: } 1 \times 2 \mathrm{~g} \text { immediately before surgery } \\
\text { Postop: } 1 \times 1 \mathrm{~g} / \text { day for } 4 \text { days }\end{array}$ & $\begin{array}{l}\text { Preop: i.v. } \\
\text { Postop: p.o. }\end{array}$ & Placebo \\
\hline 17 & Safaei 2017 [36] & 87 elective isolated $\mathrm{CABG}$ with $\mathrm{CPB}$ & $\begin{array}{l}\text { Group 1: } 4 \times 100 \mathrm{mg} \text { GSE } 24 \mathrm{~h} \text { before operation } \\
\text { Group 2: } 25 \mathrm{mg} / \mathrm{kg} \text { vitamin C during surgery }\end{array}$ & i.v. & Standard of care \\
\hline 18 & Sarzaeem 2014 [37] & $170 \mathrm{CABG}$ & $\begin{array}{l}\text { Preop: } 2 \mathrm{~g} \text { the night before surgery } \\
\text { Postop: } 2 \times 500 \mathrm{mg} / \text { day for } 5 \text { days }\end{array}$ & i.v. & Placebo \\
\hline 19 & Van Wagoner 2003 [23] & 346 CABG & $\begin{array}{l}\text { Preop: } 2 \mathrm{~g} \text { the night before surgery } \\
\text { Postop: } 2 \times 500 \mathrm{mg} / \text { day for } 5 \text { days }\end{array}$ & n.a. & Placebo \\
\hline
\end{tabular}




\subsection{Risk of Bias Assessment}

Risk of bias varied across the studies included, and insufficient detail was provided to inform judgement in several included studies (see Figures 2 and 3 for an overview and Appendix C for full details).

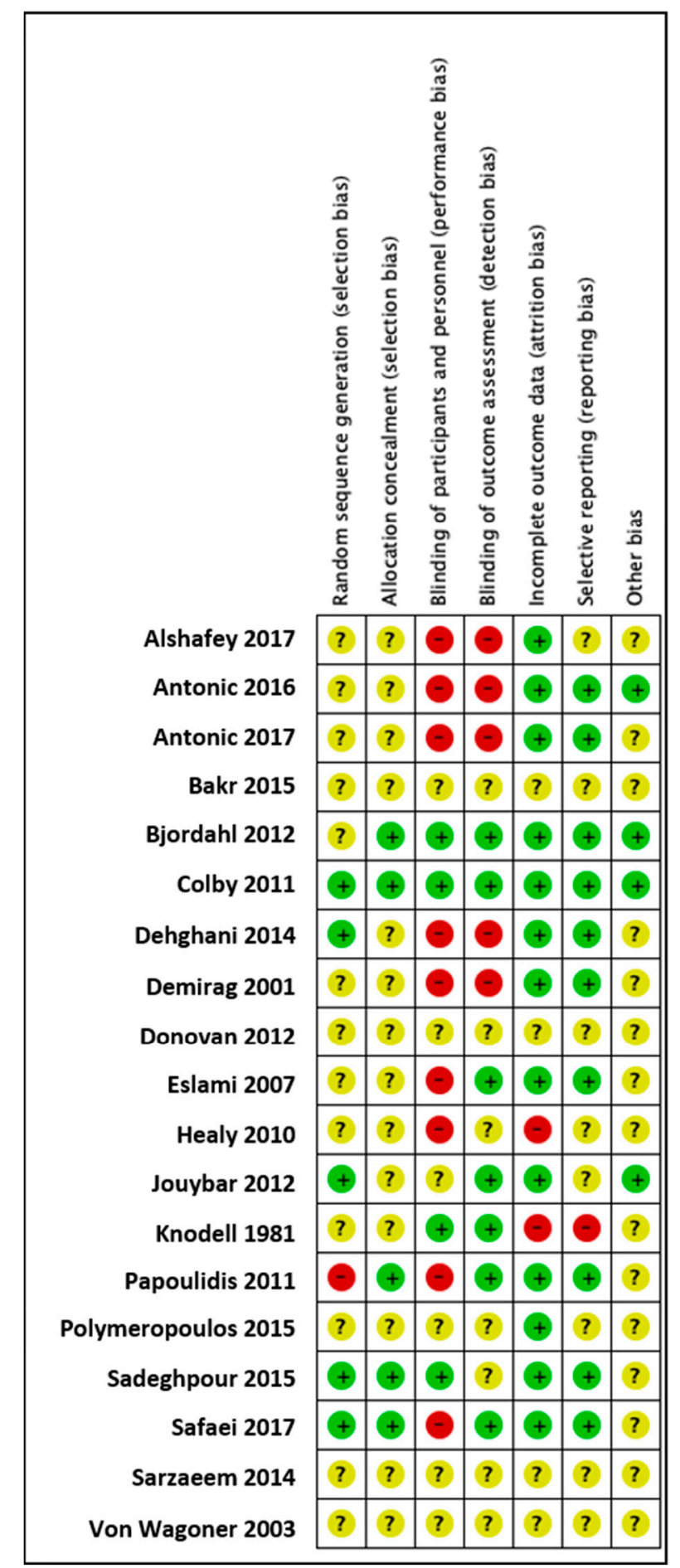

Figure 2. Risk of bias summary. 


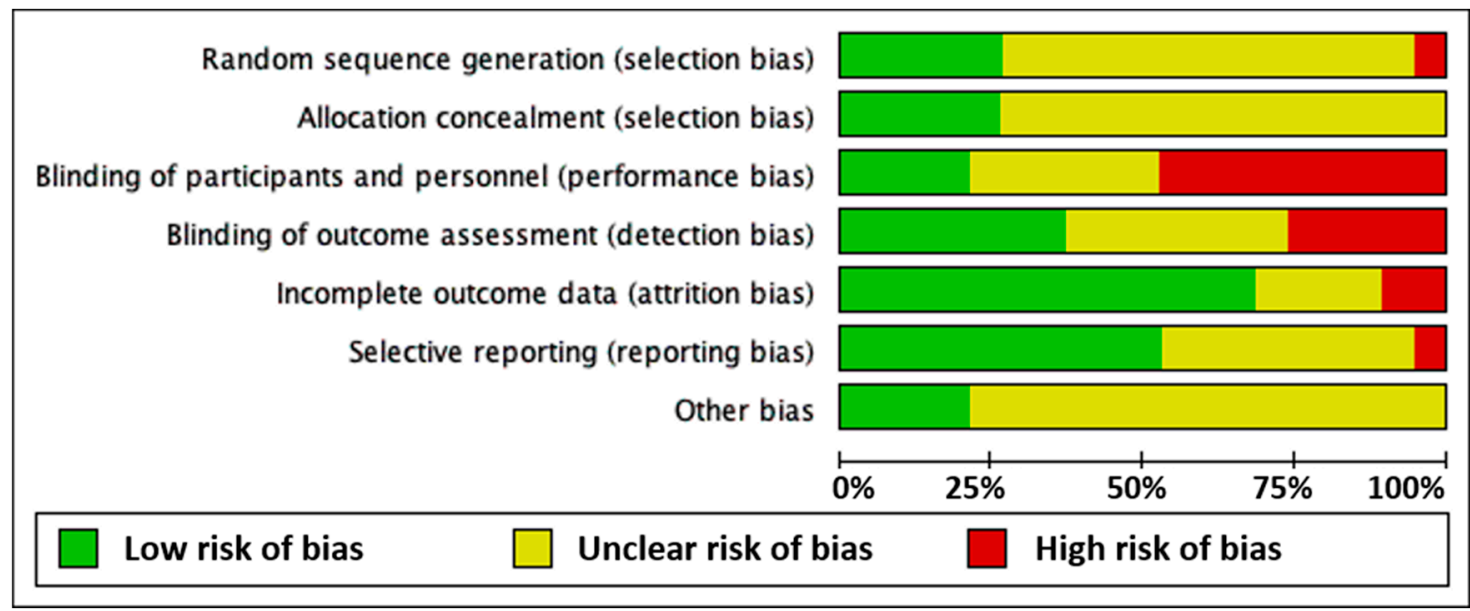

Figure 3. Risk of bias graph.

\section{Organ Function}

Due to heterogeneity in outcome definition, measurement, and reporting, we were not able to perform meta-analysis on all endpoints; however, when pooling of data was not indicated, we provide a narrative overview to have an all-encompassing picture of the effects of vitamin $C$ on organ function.

\subsection{Neurologic Function}

No study reported on postoperative cognitive dysfunction or delirium. Nine studies including 942 patients reported on the occurrence of stroke as shown in Figure 4. In three of these, no stroke occurred in either group, and results were not estimable in meta-analysis. On average, no significant effect of vitamin $C$ on the occurrence of stroke was observed ( $p=0.32$, confidence interval (CI) 0.14 to 1.91 ) with a very low overall incidence of stroke (8/942 patients, $0.85 \%)$. No statistical heterogeneity was observed $\left(\mathrm{I}^{2}=0 \%\right)$.

\begin{tabular}{|c|c|c|c|c|c|c|c|c|c|c|}
\hline Study or Subgroup & \multicolumn{2}{|c|}{ Vitamin C } & \multicolumn{2}{|c|}{ Control } & Weight & $\begin{array}{c}\text { Risk Ratio } \\
\text { M-H, Random, } 95 \% \mathrm{Cl}\end{array}$ & \multicolumn{4}{|c|}{$\begin{array}{c}\text { Risk Ratio } \\
\text { M-H, Random, } 95 \% \mathrm{Cl}\end{array}$} \\
\hline Alshafey 2017 & 0 & 50 & 0 & 50 & & Not estimable & & & & \\
\hline Antonic 2016 & 0 & 52 & 0 & 53 & & Not estimable & & & & \\
\hline Antonic 2017 & 0 & 50 & 0 & 50 & & Not estimable & & & & \\
\hline Bjordahl 2012 & 0 & 89 & 2 & 96 & $18.9 \%$ & $0.22[0.01,4.43]$ & & & & \\
\hline Colby 2011 & 0 & 13 & 0 & 11 & & Not estimable & & & & \\
\hline Dehghani 2014 & 0 & 50 & 1 & 50 & $17.1 \%$ & $0.33[0.01,7.99]$ & & & & \\
\hline Eslami 2007 & 2 & 50 & 2 & 50 & $46.9 \%$ & $1.00[0.15,6.82]$ & & & & \\
\hline Papoulidis 2011 & 0 & 85 & 1 & 85 & $17.0 \%$ & $0.33[0.01,8.07]$ & & & & \\
\hline Safaei 2017 & 0 & 29 & 0 & 29 & & Not estimable & & & & \\
\hline Total $(95 \% \mathrm{Cl})$ & & 468 & & 474 & $100.0 \%$ & $0.51[0.14,1.91]$ & & & & \\
\hline Total events & 2 & & 6 & & & & & & & \\
\hline \multicolumn{7}{|c|}{$\begin{array}{l}\text { Heterogeneity: } \operatorname{Tau}^{2}=0.00 ; \mathrm{Chi}^{2}=0.93, \mathrm{df}=3(P=0.82) ;\left.\right|^{2}=0 \% \\
\text { Test for overall effect: } Z=0.99(P=0.32)\end{array}$} & 0.01 & $\begin{array}{c}0.1 \\
\text { Favors vitamin C }\end{array}$ & $\begin{array}{c}10 \\
\text { Favors control }\end{array}$ & 100 \\
\hline
\end{tabular}

Figure 4. Total cerebral ischemic events.

\subsection{Cardiac Function}

One study reported on postoperative vasopressor requirement and found a trend towards reduced number of patients requiring postoperative vasopressors in the vitamin $C$ group (1/29 vs. 7/29 patients, $p=0.074$ ) [36]. Another study reported on the duration of postoperative vasopressor treatment and observed no difference between the groups $(1.1 \pm 1.2$ days [vitamin C] vs, $1.1 \pm 1.3$ days [control], $p=0.940$ ) [26]. Two studies reported on use of inotropes during the first $24 \mathrm{~h}$ after surgery, which was significantly lower in the control group ( $56 \%$ vitamin C group vs. $36 \%$ in the control group, $p=0.045$ ) 
in Alshafey's RCT [20] and similar (20\% in the vitamin C group vs. $22 \%$ in the control group, $p=0.81$ ) in the RCT by Eslami et al. [31]. No study reported on cumulative or maximum vasopressor dosage as surrogate parameters of cardiac dysfunction.

One study reported on postoperative ejection fraction, which was significantly higher in patients receiving vitamin $C$ either intravenously or orally administered as grape seed extract $(49.7 \pm 1.0 \mathrm{vs}$. $41.7 \pm 1.5, p=0.002$ ) [36]. One study described similar hemodynamic parameters including systolic and diastolic blood pressure and heart rate in both groups $(p=0.37)$ [32]. Thirteen studies including 1842 patients reported on atrial fibrillation in the postoperative period. On average, a significant effect in favor of vitamin $C$ was observed ( $p<0.0001$, CI 0.46 to 0.77 ), Figure 5. High statistical heterogeneity was observed $\left(\mathrm{I}^{2}=55 \%\right)$. In addition, one study reported arrhythmias requiring treatment, which was not significantly different between the groups (2/29 in the vitamin C group vs. 6/29 in the control group, $p=0.31$ ) [36].

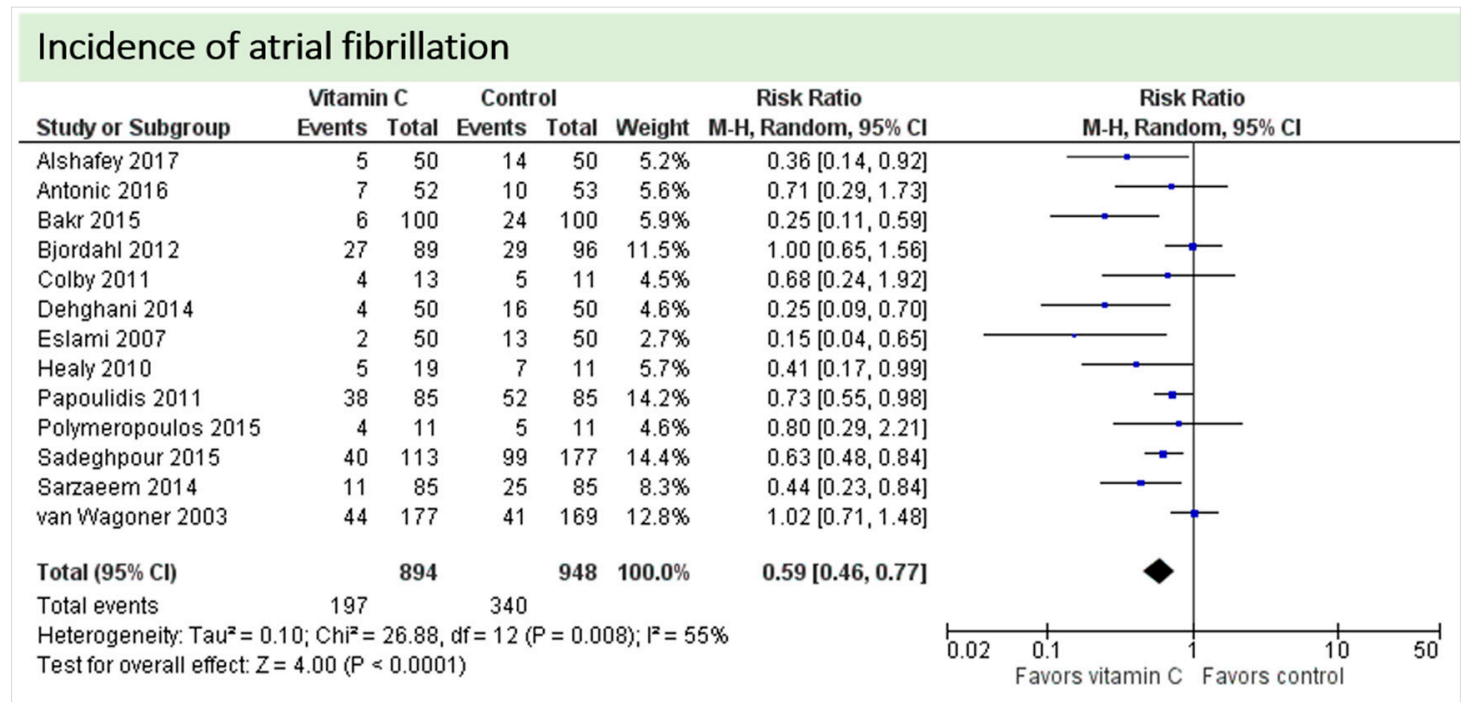

Figure 5. Incidence of postoperative atrial fibrillation.

\subsection{Pulmonary Function}

No study reported on the need for non-invasive ventilator support, oxygen requirement or pleural effusions as surrogate parameters of pulmonary function. Four studies including 633 patients reported on ventilation time in hours as shown in Figure 6. Two studies reported results in favor of vitamin C, two studies were neutral. On average, the effect of vitamin $C$ was significant on reduction of ventilation time ( $p=0.0003, \mathrm{CI}-3.99$ to -1.18$)$; we observed no statistical heterogeneity $\left(\mathrm{I}^{2}=0 \%\right)$. The effect of vitamin $C$ was more pronounced in studies with intravenous administration of vitamin $C[19,36]$.

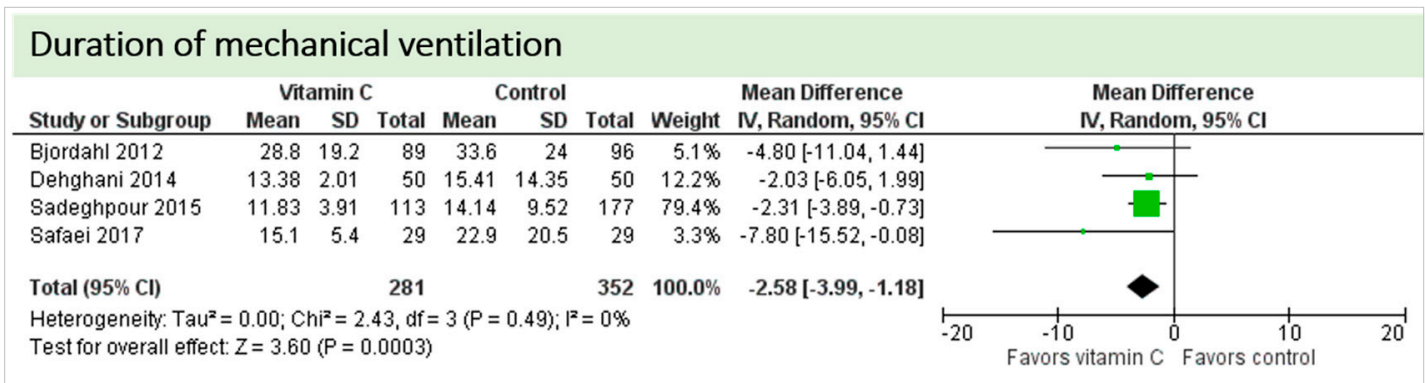

Figure 6. Duration of mechanical ventilation in hours. 


\subsection{Renal Function}

Two studies including 127 patients reported on acute kidney injury $[25,36]$. In the study by Antonic et al., vitamin $C$ had no effect on the occurrence of acute kidney injury $(p=0.779)$, maximum postoperative serum creatinine $(p=0.434)$ or lowest postoperative creatinine clearance $(p=0.766)$. No patient received renal replacement therapy in either group in this study [25]. The study by Safaei et al. reported no acute kidney failure in either study groups (each 0/29) [36]. One study described "similar serum potassium, blood urea nitrogen and creatinine levels" in both groups, without presenting more detailed information [32]. Overall only insufficient data were available about the exact definition of acute kidney injury in these patients.

\subsection{Adverse Events}

Adverse events (as defined by trial authors) included stroke, sternal wound infection, sepsis, cardiac arrest, "some complications" (death, impaired renal function and infection), need for intra-aortic balloon pump, post-transfusion hepatitis, reoperation, and drainage volume. Pooling of data in metaanalysis was deemed as inappropriate due to the heterogeneity in outcome definition, measurement and reporting.

\subsection{In-Hospital Mortality}

Nine studies including 1315 patients reported on this outcome. In five studies, no deaths occurred, and data could not be estimated. On average, no significant effect of vitamin $C$ was found on in-hospital mortality ( $p=0.59$, CI 0.21 to 2.40 ), as shown in Figure 7. One study described two in-hospital deaths but did not specify the groups of the respective patients [24]. No statistical heterogeneity was observed $\left(\mathrm{I}^{2}=0 \%\right)$.

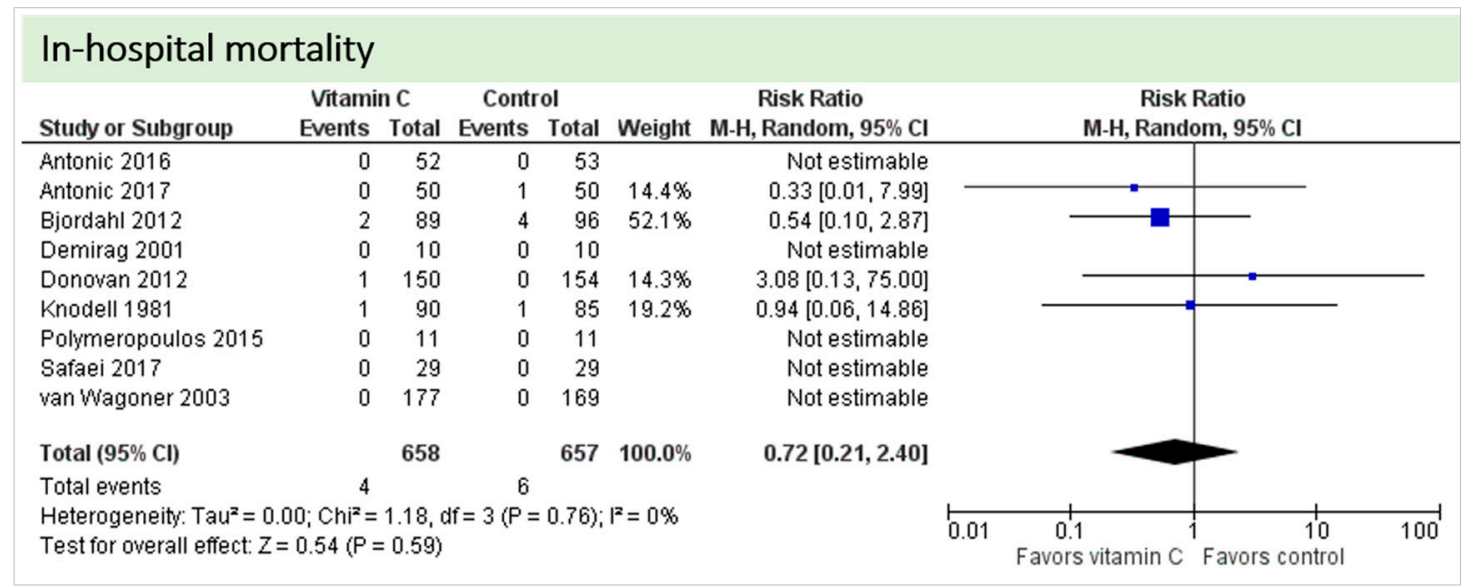

Figure 7. In-hospital mortality.

\subsection{Length of Stay}

Eleven studies including 1402 patients reported on ICU-LOS as shown in Figure 8. One study reported longer overall ICU-LOS than all other RCTs [27]. On average, a significant effect favoring vitamin $\mathrm{C}$ administration was detected ( $p=0.002, \mathrm{CI}-9.66$ to -2.14$)$. High statistical heterogeneity was observed $\left(\mathrm{I}^{2}=62 \%\right)$. 


\begin{tabular}{|c|c|c|c|c|c|c|c|c|c|c|c|c|}
\hline \multicolumn{13}{|c|}{ Intensive care unit length-of-stay } \\
\hline Study or Subgroup & \multicolumn{3}{|c|}{ Vitamin C } & \multicolumn{3}{|c|}{ Control } & Weight & $\begin{array}{l}\text { Mean Difference } \\
\text { IV, Random, } 95 \% \mathrm{CI}\end{array}$ & \multicolumn{4}{|c|}{$\begin{array}{c}\text { Mean Difference } \\
\text { IN, Random, } 95 \% \mathrm{Cl}\end{array}$} \\
\hline Alshafey 2017 & 66.72 & 31.92 & 50 & 85.92 & 17.52 & 50 & $8.0 \%$ & $-19.20[-29.29,-9.11]$ & & & & \\
\hline Antonic 2016 & 36 & 25.44 & 52 & 31.2 & 16.56 & 53 & $9.9 \%$ & $4.80[-3.43,13.03]$ & & & & \\
\hline Antonic 2017 & 34.08 & 24.24 & 50 & 33.12 & 18 & 50 & $9.8 \%$ & $0.96[-7.41,9.33]$ & & & & \\
\hline Bjordahl 2012 & 88.8 & 52.8 & 89 & 103.2 & 69.6 & 96 & $3.6 \%$ & $-14.40[-32.12,3.32]$ & & & & \\
\hline Colby 2011 & 106.4 & 249.9 & 13 & 48.9 & 43.2 & 11 & $0.1 \%$ & $57.50[-80.72,195.72]$ & & & & \\
\hline Dehghani 2014 & 42.96 & 7.512 & 50 & 50.4 & 14.64 & 50 & $14.8 \%$ & $-7.44[-12.00,-2.88]$ & & $\rightarrow$ & & \\
\hline Eslami 2007 & 55.2 & 38.4 & 50 & 62.4 & 35.52 & 50 & $5.0 \%$ & $-7.20[-21.70,7.30]$ & & & & \\
\hline Papoulidis 2011 & 38.4 & 21.6 & 85 & 50.4 & 26.4 & 85 & $11.1 \%$ & $-12.00[-19.25,-4.75]$ & & $\longrightarrow$ & & \\
\hline Sadeghpour 2015 & 82.08 & 25.44 & 113 & 82.32 & 26.16 & 177 & $12.7 \%$ & $-0.24[-6.31,5.83]$ & & $\rightarrow$ & - & \\
\hline Safaei 2017 & 67 & 3 & 29 & 71.2 & 6.1 & 29 & $17.5 \%$ & $-4.20[-6.67,-1.73]$ & & - & & \\
\hline Sarzaeem 2014 & 60 & 33.6 & 85 & 72 & 38.4 & 85 & $7.4 \%$ & $-12.00[-22.85,-1.15]$ & & & & \\
\hline Total $(95 \% \mathrm{Cl})$ & & & 666 & & & 736 & $100.0 \%$ & $-5.90[-9.66,-2.14]$ & & & & \\
\hline $\begin{array}{l}\text { Heterogeneity: Tau }{ }^{2}= \\
\text { Test for overall effect }\end{array}$ & $\begin{array}{l}19.39 ; 0 \\
Z=3.07\end{array}$ & $\begin{array}{l}C h i^{2}=2 \\
(P=0 .\end{array}$ & $\begin{array}{l}6.00, d f \\
002)\end{array}$ & $f=10(P$ & $=0.004$ & 4); $\left.\right|^{2}=6$ & & & -50 & $\begin{array}{cc}-25 & + \\
\text { Favors vitamin C }\end{array}$ & $\begin{array}{cc} & 25 \\
\text { Favors control }\end{array}$ & 50 \\
\hline
\end{tabular}

Figure 8. Intensive care unit (ICU) length of stay.

Eight studies including 1244 patients reported on hospital-LOS. The study by Colby et al. [27] reported much longer hospital stays than the other studies. On average, there was a significant effect in favor of vitamin $C(p=0.03, C I-34.49$ to -1.41$)$. We observed high statistical heterogeneity $\left(\mathrm{I}^{2}=81 \%\right)$ (Figure 9).

\begin{tabular}{|c|c|c|c|c|c|c|c|c|c|c|c|c|}
\hline \multicolumn{13}{|c|}{ Hospital length-of-stay } \\
\hline \multirow[b]{2}{*}{ Study or Subgroup } & \multicolumn{3}{|c|}{ Vitamin C } & \multicolumn{3}{|c|}{ Control } & \multirow[b]{2}{*}{ Weight } & \multirow{2}{*}{$\begin{array}{l}\text { Mean Difference } \\
\text { IV, Random, 95\% CI }\end{array}$} & \multirow{2}{*}{\multicolumn{4}{|c|}{$\begin{array}{c}\text { Mean Difference } \\
\text { IV, Random, } 95 \% \mathrm{Cl}\end{array}$}} \\
\hline & Mean & SD & Total & Mean & SD & Total & & & & & & \\
\hline Antonic 2016 & 224.88 & 61.68 & 52 & 210.48 & 33.6 & 53 & $13.4 \%$ & $14.40[-4.65,33.45]$ & & & $\longrightarrow$ & \\
\hline Antonic 2017 & 223.68 & 60.48 & 50 & 211.2 & 37.92 & 50 & $13.2 \%$ & $12.48[-7.31,32.27]$ & & & & \\
\hline Bjordahl 2012 & 249.6 & 96 & 89 & 280.8 & 170.4 & 96 & $8.4 \%$ & $-31.20[-70.69,8.29]$ & & & - & \\
\hline Colby 2011 & 350.4 & 422.4 & 13 & 244.8 & 117.6 & 11 & $0.5 \%$ & $105.60[-134.30,345.50]$ & & & & \\
\hline Dehghani 2014 & 127.68 & 14.16 & 50 & 137.76 & 31.2 & 50 & $15.4 \%$ & $-10.08[-19.58,-0.58]$ & & 0 & & \\
\hline Eslami 2007 & 156.96 & 77.76 & 50 & 169.92 & 82.8 & 50 & $10.2 \%$ & $-12.96[-44.44,18.52]$ & & & & \\
\hline Papoulidis 2011 & 189.6 & 52.8 & 85 & 235.2 & 86.4 & 85 & $12.7 \%$ & $-45.60[-67.13,-24.07]$ & & & & \\
\hline Sadeghpour 2015 & 244.08 & 111.12 & 113 & 288 & 108.24 & 177 & $11.6 \%$ & $-43.92[-69.88,-17.96]$ & & & & \\
\hline Sarzaeem 2014 & 158.4 & 36 & 85 & 196.8 & 55.2 & 85 & $14.6 \%$ & $-38.40[-52.41,-24.39]$ & & & & \\
\hline Total $(95 \% \mathrm{Cl})$ & & & 587 & & & 657 & $100.0 \%$ & $-17.95[-34.49,-1.41]$ & & & & \\
\hline \multicolumn{9}{|c|}{$\begin{array}{l}\text { Heterogeneity: } \mathrm{Tau}^{2}=438.15 ; \mathrm{Chi}^{2}=42.35, \mathrm{df}=8(\mathrm{P}<0.00001) ; \mathrm{l}^{2}=81 \% \\
\text { Test for overall effect: } Z=2.13(\mathrm{P}=0.03)\end{array}$} & -100 & $\begin{array}{cc} \\
-50 \\
\text { Favors vitamin } C\end{array}$ & $\begin{array}{cc}50 \\
\text { Favors control }\end{array}$ & 100 \\
\hline
\end{tabular}

Figure 9. Hospital length of stay.

4.8. Subgroup Analysis Influence of Administration Route: Intravenous Administration versus Oral Administration of Vitamin C

This subgroup analysis was performed to investigate any possible influence of the route of administration (intravenous administration versus oral administration of vitamin C) on study results; available data allowed assessment of the outcomes cerebral ischemic events, incidence of atrial fibrillation, in-hospital mortality, ICU-LOS, hospital-LOS, and duration of mechanical ventilation.

A total of eight studies contributed reported the outcome "cerebral ischemic events" and contributed to the subgroup analysis investigating any possible influence of the route of administration, as shown in Figure 10. In four of the eight studies, cerebral ischemic events occurred and the evidence suggested no difference in treatment effect (test for subgroup differences $\left(\mathrm{Chi}^{2}=0.09, \mathrm{df}=1(p=0.99)\right.$, $\left.\mathrm{I}^{2}=0 \%\right)$. 


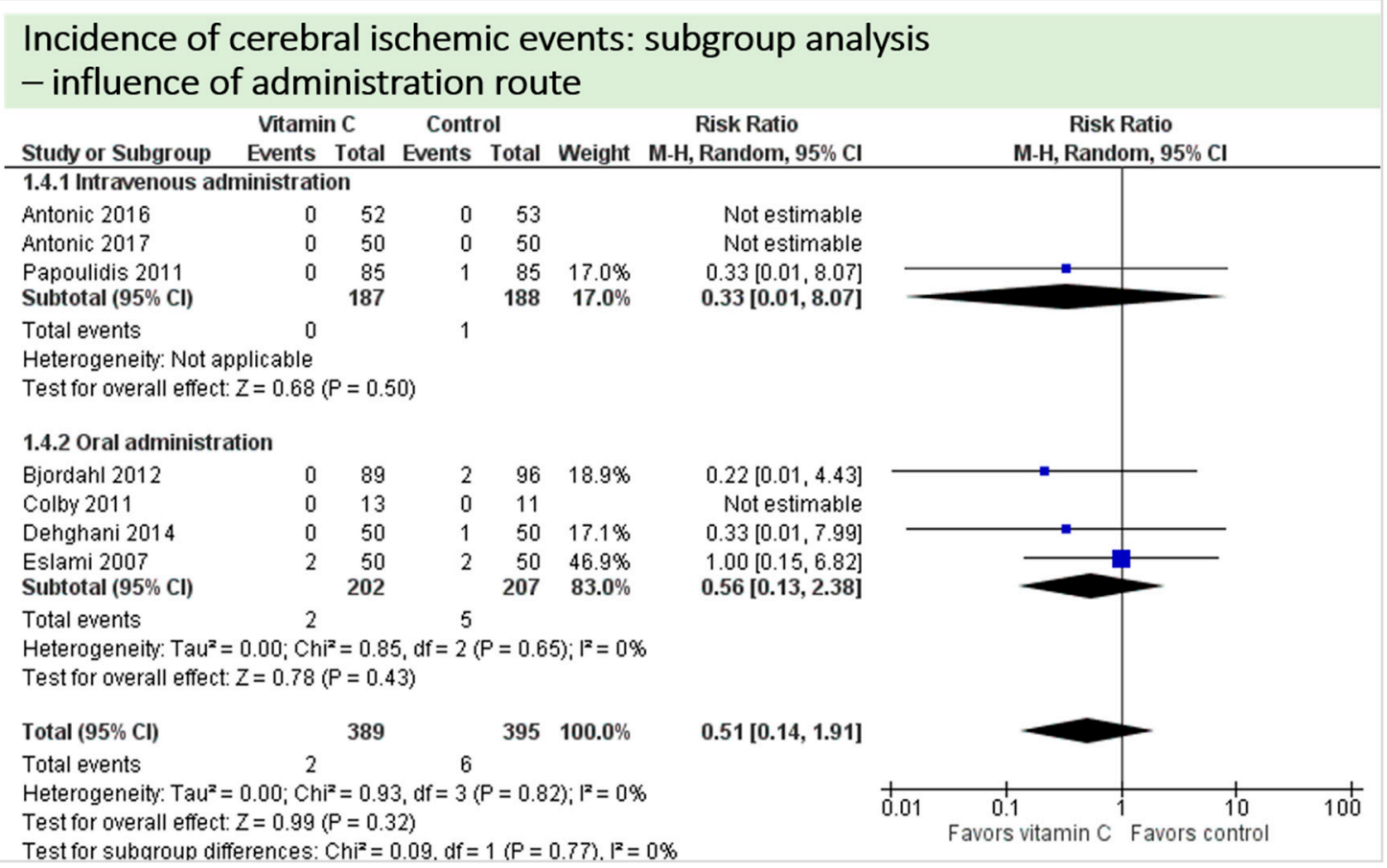

Figure 10. Cerebral ischemic events: subgroup analysis-influence of administration route.

A total of eight studies contributed to the subgroup analysis investigating any possible influence of the route of administration on the outcome incidence of "atrial fibrillation", as shown in Figure 11. While the effect of the treatment was statistically significant in the group receiving intravenous vitamin $C$ $\left(p=0.002, \mathrm{CI} 0.53\right.$ to $\left.0.87, \mathrm{I}^{2}=0 \%\right)$, it was not in patients receiving oral vitamin C $(p=0.09, \mathrm{CI} 0.19$ to $\left.1.13, \mathrm{I}^{2}=74 \%\right)$. However, the test for subgroup differences $\left(\mathrm{Chi}^{2}=0.69, \mathrm{df}=1(\mathrm{P}=0.41), \mathrm{I}^{2}=0 \%\right)$ shows no evidence that the effect of vitamin $C$ is different between the trials that used intravenous administration and those that used oral administration on the outcome incidence of "atrial fibrillation".

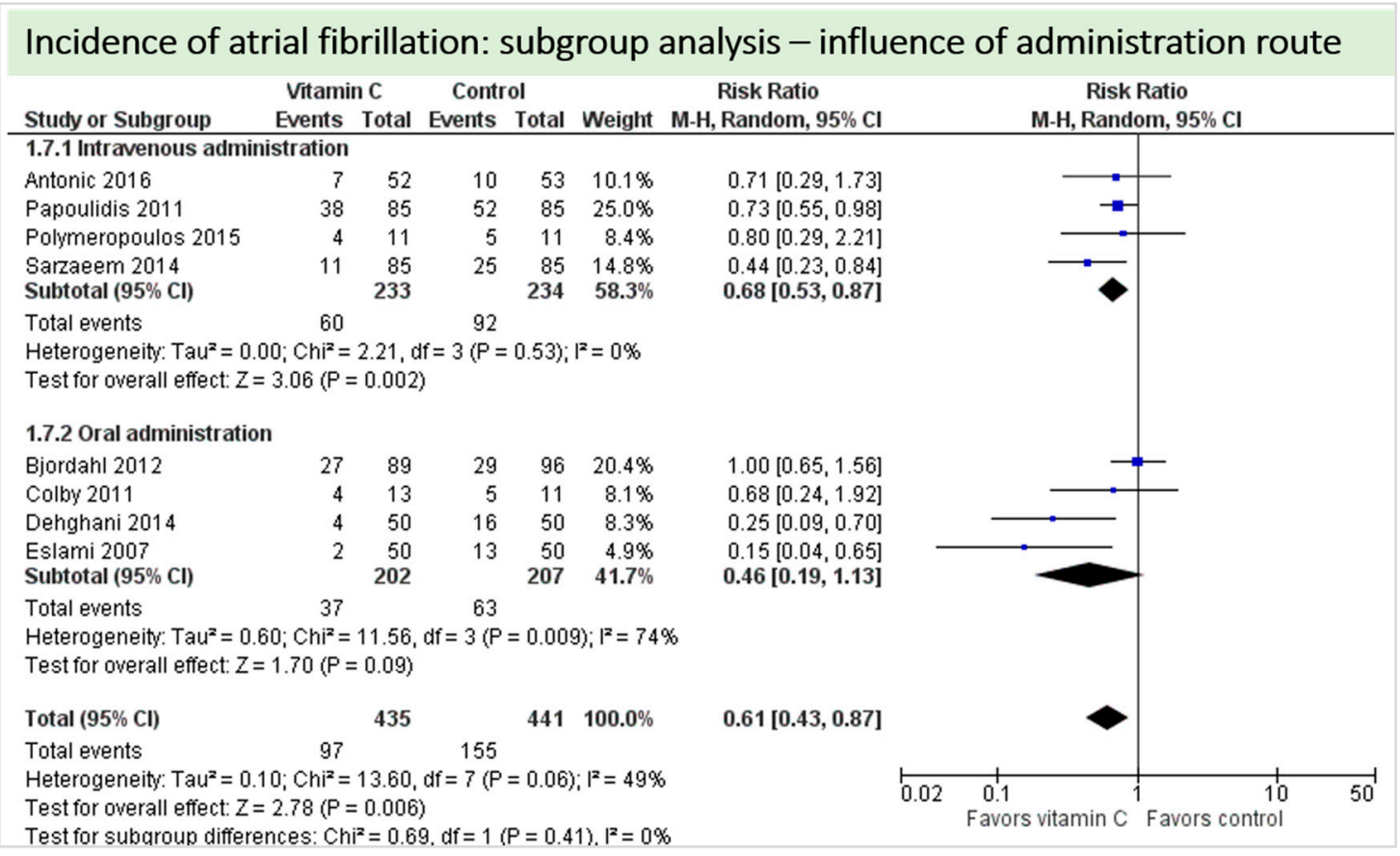

Figure 11. Incidence of atrial fibrillation: subgroup analysis-influence of administration route. 
A total of four studies contributed to the subgroup analysis investigating any possible influence of the route of administration on the outcome "duration of mechanical ventilation", as shown in Figure 12. We found a statistical significance in the group receiving intravenous vitamin $\mathrm{C}(p=0.05$, $\mathrm{CI}-15.52$ to $-0.08, \mathrm{I}^{2}$ not applicable); however, this group included only one RCT with 58 patients in total. In the group of oral vitamin $\mathrm{C}$ administration, the treatment effect did not reach statistical significance $\left(p=0.10, \mathrm{CI}-6.22\right.$ to $\left.0.54, \mathrm{I}^{2}=0 \%\right)$. The test for subgroup differences $\left(\mathrm{Chi}^{2}=1.89, \mathrm{df}=2\right.$ $\left.(p=0.39), \mathrm{I}^{2}=0 \%\right)$ shows no evidence that the effect of vitamin $\mathrm{C}$ is different between the trials that used intravenous administration and those that used oral administration on the outcome incidence of "duration of mechanical ventilation".

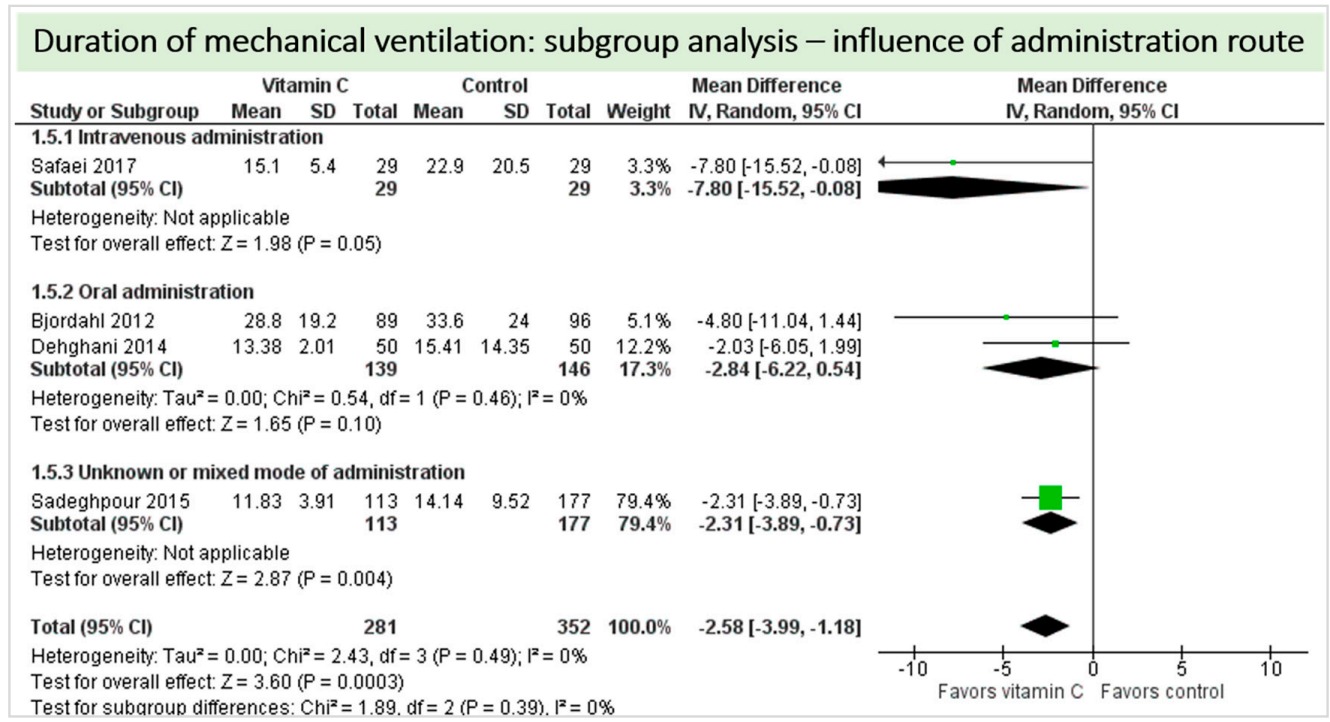

Figure 12. Duration of mechanical ventilation in hours: subgroup analysis-influence of administration route.

A total of eight studies contributed to the subgroup analysis investigating any possible influence of the route of administration on the outcome "in-hospital mortality", as shown in Figure 13. We found no evidence of a treatment effect between subgroups (test for subgroup differences $\left(\mathrm{Chi}^{2}=0.26, \mathrm{df}=1\right.$ $\left.(p=0.61), \mathrm{I}^{2}=0 \%\right)$

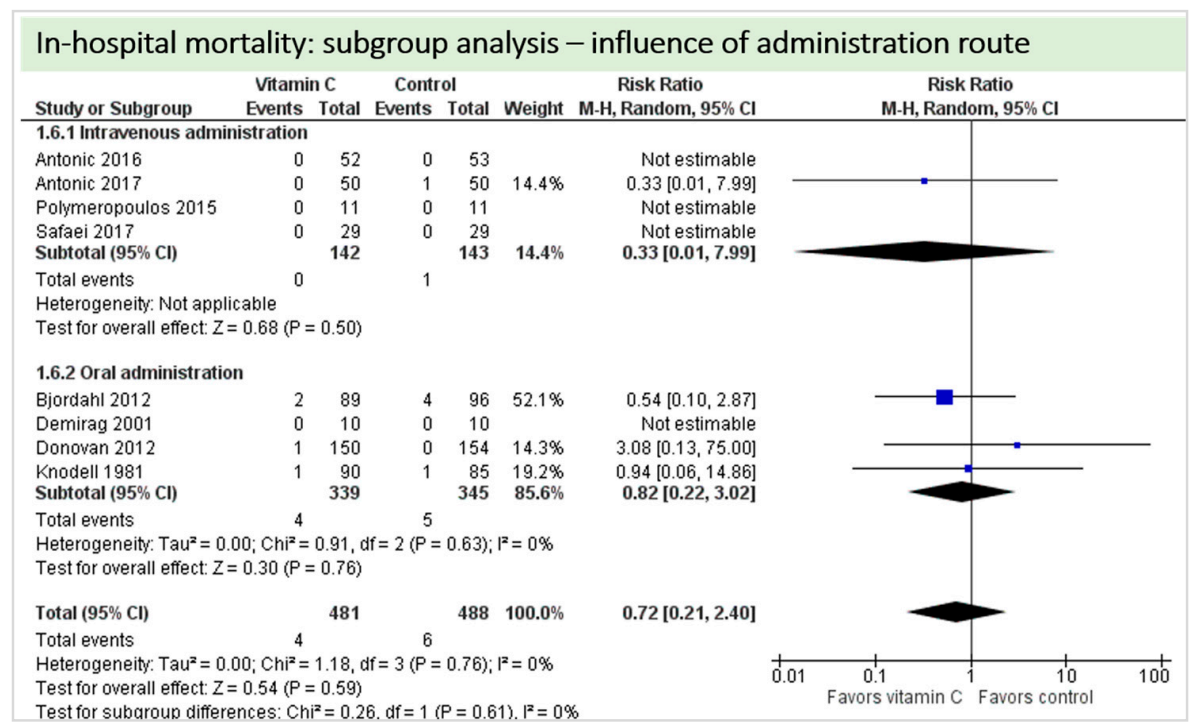

Figure 13. In-hospital mortality: subgroup analysis-Influence of administration route. 
A total of nine studies contributed to the subgroup analysis investigating any possible influence of the route of administration on the outcome "ICU-LOS", as shown in Figure 14. We found no statistically significant effects in the group receiving intravenous vitamin $C(p=0.12, C I-9.64$ to 1.07 , $\mathrm{I}^{2}=68 \%$ ), but in the group of oral vitamin $\mathrm{C}$ administration, the treatment effect did reach statistical significance $\left(p=0.0003, \mathrm{CI}-11.98\right.$ to $\left.-3.53, \mathrm{I}^{2}=0 \%\right)$. The test for subgroup differences $\left(\mathrm{Chi}^{2}=1.00\right.$, $\left.\mathrm{df}=1(p=0.32), \mathrm{I}^{2}=0 \%\right)$ shows no evidence that the effect of vitamin $\mathrm{C}$ is different between the trials that used intravenous administration and those that used oral administration on the outcome "ICU-LOS".

\begin{tabular}{|c|c|c|c|c|c|c|c|c|c|c|c|c|}
\hline \multirow[b]{2}{*}{ Study or Subgroup } & \multicolumn{3}{|c|}{ Vitamin C } & \multicolumn{3}{|c|}{ Control } & \multirow{3}{*}{ Weight } & \multirow{2}{*}{$\begin{array}{l}\text { Mean Difference } \\
\mathrm{N}, \text { Random, } 95 \% \mathrm{Cl}\end{array}$} & \multirow{2}{*}{\multicolumn{4}{|c|}{$\begin{array}{l}\text { Mean Difference } \\
\text { IV, Random, } 95 \% \mathrm{Cl}\end{array}$}} \\
\hline & Mean & SD & Total & Mean & SD & Total & & & & & & \\
\hline \multicolumn{12}{|c|}{ 1.1.1 Intravenous administration } & \\
\hline Antonic 2016 & 36 & 25.44 & 52 & 31.2 & 16.56 & 53 & $11.9 \%$ & $4.80[-3.43,13.03]$ & & & $\rightarrow$ & \\
\hline Antonic 2017 & 34.08 & 24.24 & 50 & 33.12 & 18 & 50 & $11.6 \%$ & $0.96[-7.41,9.33]$ & & & - & \\
\hline Papoulidis 2011 & 38.4 & 21.6 & 85 & 50.4 & 26.4 & 85 & $13.7 \%$ & $-12.00[-19.25,-4.75]$ & & & & \\
\hline Safaei 2017 & 67 & 3 & 29 & 71.2 & 6.1 & 29 & $25.4 \%$ & $-4.20[-6.67,-1.73]$ & & -- & & \\
\hline $\begin{array}{l}\text { Sarzaeem } 2014 \\
\text { Subtotal }(95 \% \mathrm{Cl})\end{array}$ & 60 & 33.6 & $\begin{array}{r}85 \\
301\end{array}$ & 72 & 38.4 & $\begin{array}{r}85 \\
302\end{array}$ & $\begin{array}{r}8.3 \% \\
70.9 \%\end{array}$ & $\begin{array}{r}-12.00[-22.85,-1.15] \\
-4.28[-9.64,1.07]\end{array}$ & & & & \\
\hline \multicolumn{13}{|c|}{$\begin{array}{l}\text { Heterogeneity: } \text { Tau }^{2}=23.33 ; \mathrm{Ch}^{2}=12.49, \mathrm{df}=4(\mathrm{P}=0.01) ; \mathrm{I}^{2}=68 \% \\
\text { Test for overall effect: } Z=1.57(\mathrm{P}=0.12)\end{array}$} \\
\hline \multicolumn{13}{|c|}{ 1.1.2 Oral administration } \\
\hline Bjordahl 2012 & 88.8 & 52.8 & 89 & 103.2 & 69.6 & 96 & $3.8 \%$ & $-14.40[-32.12,3.32]$ & & & - & \\
\hline Colby 2011 & 106.4 & 249.9 & 13 & 48.9 & 43.2 & 11 & $0.1 \%$ & $57.50[-80.72,195.72]$ & & & & \\
\hline Dehghani 2014 & 42.96 & 7.512 & 50 & 50.4 & 14.64 & 50 & $20.0 \%$ & $-7.44[-12.00,-2.88]$ & & $\rightarrow-$ & & \\
\hline $\begin{array}{l}\text { Eslami } 2007 \\
\text { Subtotal }(95 \% \mathrm{Cl})\end{array}$ & 55.2 & 38.4 & $\begin{array}{r}50 \\
202\end{array}$ & 62.4 & 35.52 & $\begin{array}{r}50 \\
207\end{array}$ & $\begin{array}{r}5.3 \% \\
29.1 \%\end{array}$ & $\begin{array}{r}-7.20[-21.70,7.30] \\
-7.75[-11.98,-3.53]\end{array}$ & & & & \\
\hline \multicolumn{13}{|c|}{$\begin{array}{l}\text { Heterogeneity: } \operatorname{Tau}^{2}=0.00 ; \mathrm{Chi}^{2}=1.42, \mathrm{df}=3(P=0.70) ; \mathrm{l}^{2}=0 \% \\
\text { Test for overall effect: } Z=3.60(P=0.0003)\end{array}$} \\
\hline Total $(95 \% \mathrm{Cl})$ & & & 503 & & & 509 & $100.0 \%$ & $-5.39[-9.10,-1.69]$ & & & & \\
\hline \multicolumn{9}{|c|}{$\begin{array}{l}\text { Heterogeneity: } \mathrm{Tau}^{2}=12.47 ; \mathrm{Chi}^{2}=16.03, \mathrm{df}=8(\mathrm{P}=0.04) ; \mathrm{I}^{2}=50 \% \\
\text { Test for overall effect: } Z=2.85(P=0.004) \\
\text { Test for subaroup differences: } \mathrm{Chi}^{2}=1.00, \mathrm{df}=1(\mathrm{P}=0.32) . \mathrm{I}^{2}=0 \%\end{array}$} & -50 & $\begin{array}{cc}-25 \\
\text { Favors vitamin } C\end{array}$ & $\begin{array}{c}25 \\
\text { Favors control }\end{array}$ & 50 \\
\hline
\end{tabular}

Figure 14. ICU length of stay: subgroup analysis-influence of administration route.

A total of eight studies contributed to the subgroup analysis investigating any possible influence of the route of administration on the outcome "hospital-LOS", as shown in Figure 15. We found no statistical significance in the group receiving intravenous vitamin C ( $p=0.36, \mathrm{CI}-45.51$ to 16.71 , $\left.\mathrm{I}^{2}=91 \%\right)$, but in the group of oral vitamin $C$ administration, the treatment effect did reach statistical significance $\left(p=0.01, \mathrm{CI}-20.07\right.$ to $\left.-2.36, \mathrm{I}^{2}=81 \%\right)$. The test for subgroup differences $\left(\mathrm{Chi}^{2}=0.04\right.$, $\left.\mathrm{df}=1(p=0.85), \mathrm{I}^{2}=0 \%\right)$ shows no evidence that the effect of vitamin $\mathrm{C}$ is different between the trials that used intravenous administration and those that used oral administration on the outcome "hospital-LOS".

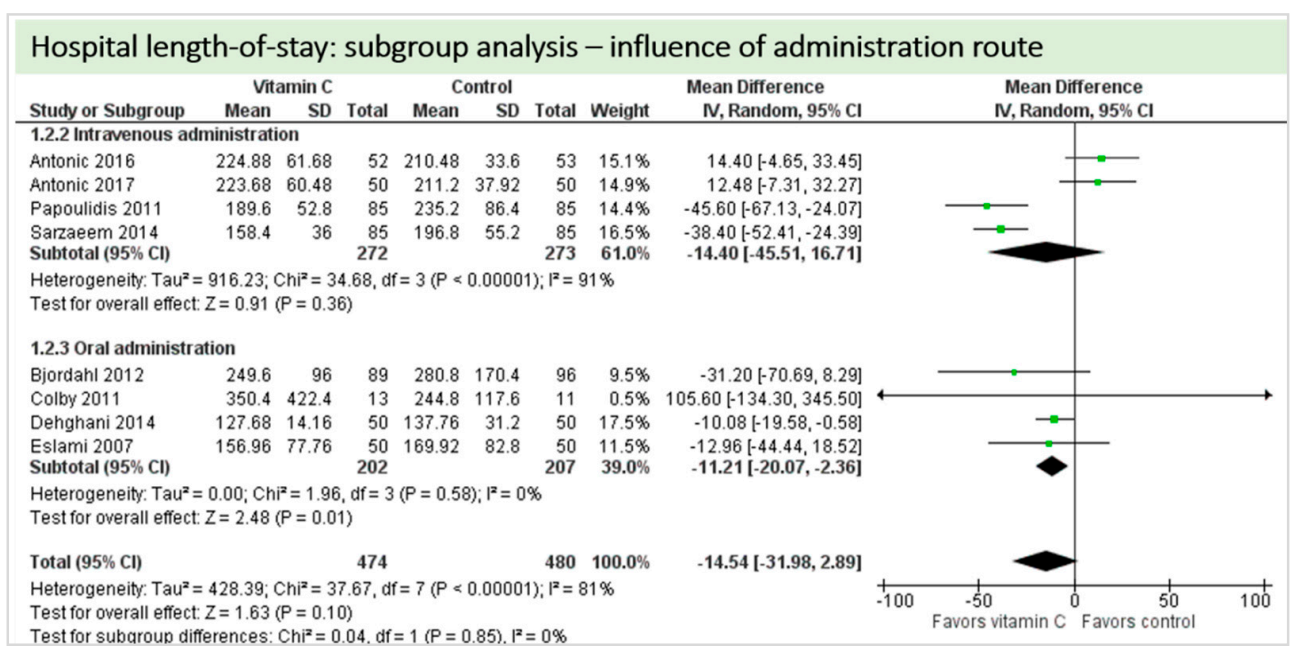

Figure 15. Hospital length of stay: subgroup analysis-influence of administration route. 


\subsection{Subgroup Analysis Influence of Control Group: "Vitamin C versus Placebo" versus "Vitamin C versus} Standard of Care"

A total of eight studies reported the outcome "cerebral ischemic events" and contributed to the subgroup analysis investigating any possible influence of the control group on the outcome, as shown in Figure 16. In four of the eight studies, cerebral ischemic events occurred. We found no evidence of a treatment effect between subgroups (test for subgroup differences $\left(\mathrm{Chi}^{2}=0.55, \mathrm{df}=1\right.$ $\left.(p=0.46), \mathrm{I}^{2}=0 \%\right)$.

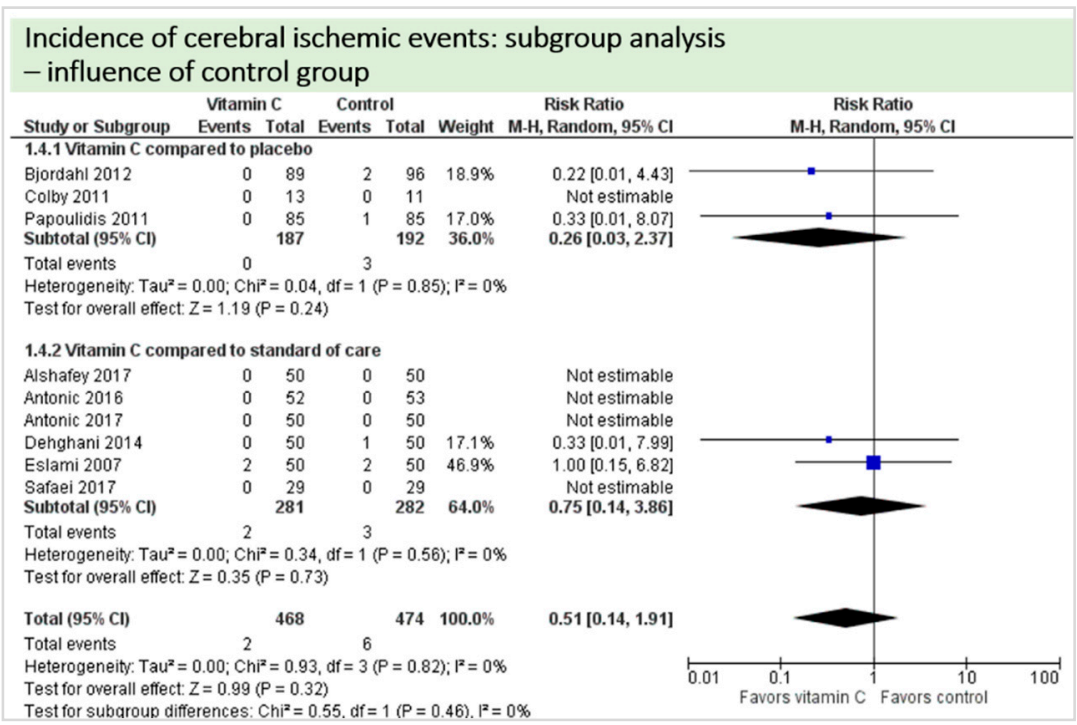

Figure 16. Cerebral ischemic events: subgroup analysis-influence of control group.

A total of thirteen studies contributed to the subgroup analysis investigating any possible influence of the control group on the outcome incidence of "atrial fibrillation", as shown in Figure 17. We found evidence of a treatment effect between subgroups (test for subgroup differences $\left(\mathrm{Chi}^{2}=11.84, \mathrm{df}=1\right.$ $(p=0.0006), \mathrm{I}^{2}=91.6 \%$ ) between the trials comparing placebo and trials comparing standard of care for the outcome "atrial fibrillation".

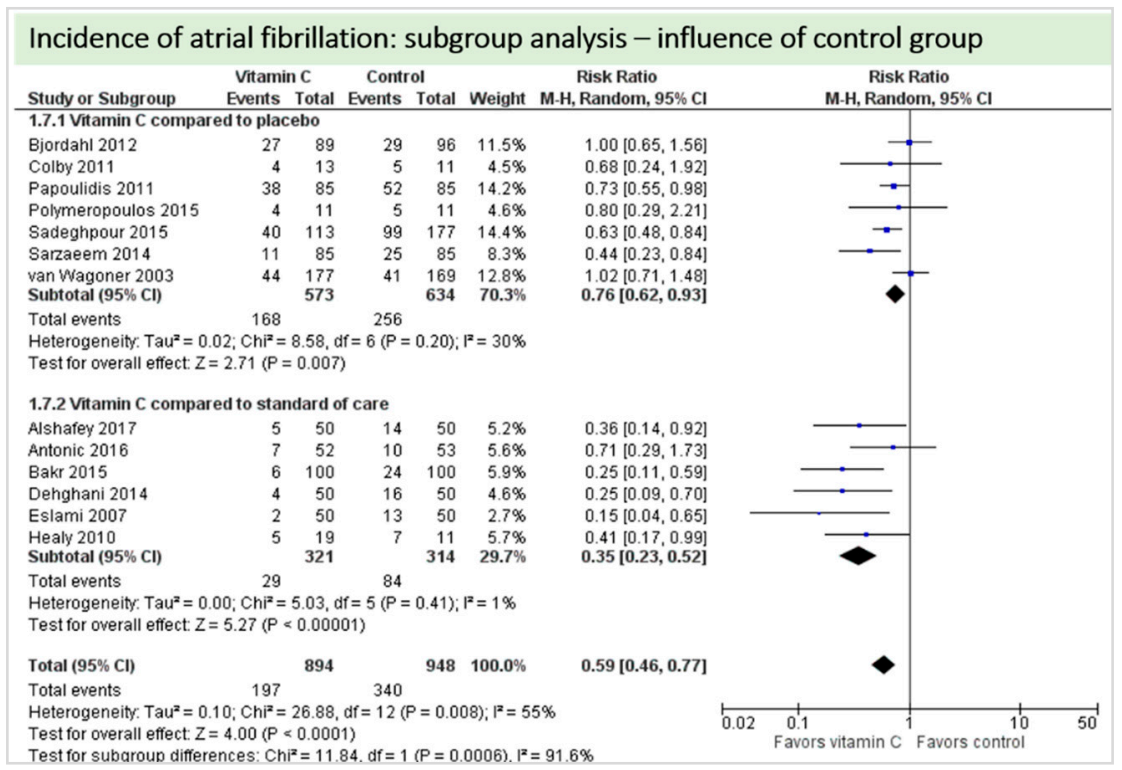

Figure 17. Incidence of atrial fibrillation: subgroup analysis-influence of control group. 
A total of four studies contributed to the subgroup analysis investigating any possible influence of the control group on the outcome "duration of mechanical ventilation", as shown in Figure 18. We found a statistical significance in the group comparing vitamin $\mathrm{C}$ to placebo $(p=0.002, \mathrm{CI}-3.99$ to $\left.-0.93, \mathrm{I}^{2}=0 \%\right)$, but not in the group comparing vitamin $\mathrm{C}$ to standard of care $(p=0.15, \mathrm{CI}-9.25$ to $\left.1.38, \mathrm{I}^{2}=41 \%\right)$. The test for subgroup differences $\left(\mathrm{Chi}^{2}=0.27, \mathrm{df}=1(p=0.60), \mathrm{I}^{2}=0 \%\right)$ shows no evidence that the effect of vitamin $C$ is different between the trials that with compared to placebo and those that compared to standard of care on the outcome "duration of mechanical ventilation".

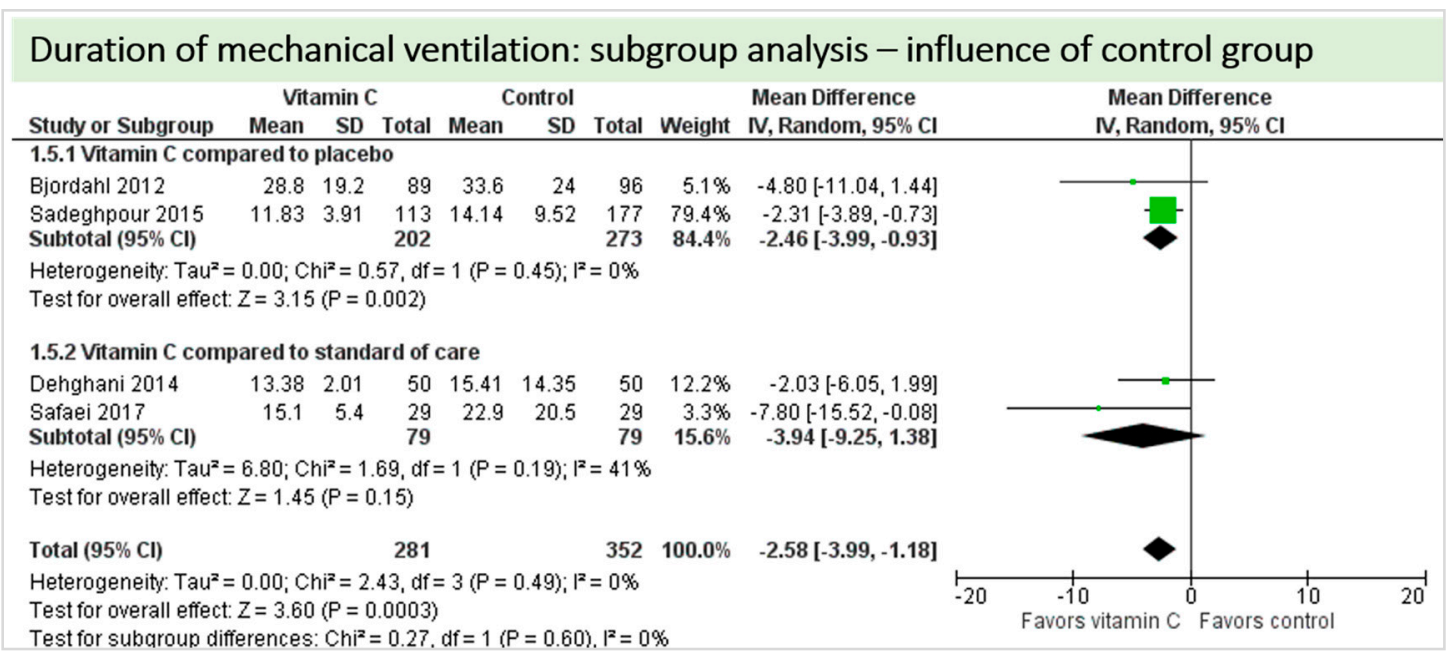

Figure 18. Duration of mechanical ventilation in hours: subgroup analysis_-influence of control group.

A total of nine studies reported the outcome "in-hospital mortality" and contributed to the subgroup analysis investigating any possible influence of the control group on the outcome, as shown in Figure 19. In-hospital deaths occurred in only four of these studies and we found no evidence of a treatment effect between subgroups (test for subgroup differences $\left(\mathrm{Chi}^{2}=0.12, \mathrm{df}=1(p=0.73)\right.$, $\left.\mathrm{I}^{2}=0 \%\right)$.

\begin{tabular}{|c|c|c|c|c|c|c|c|c|c|c|}
\hline Study or Subgroup & \multicolumn{2}{|c|}{ Vitamin C } & \multicolumn{2}{|c|}{ Control } & Weight & \multirow[t]{2}{*}{$\begin{array}{c}\text { Risk Ratio } \\
\text { M-H, Random, } 95 \% \mathrm{Cl}\end{array}$} & \multicolumn{4}{|c|}{$\begin{array}{c}\text { Risk Ratio } \\
\text { M-H, Random, } 95 \% \mathrm{Cl}\end{array}$} \\
\hline \multicolumn{10}{|c|}{ 1.6.1 Vitamin C compared to placebo } & \\
\hline Bjordahl 2012 & 2 & 89 & 4 & 96 & $52.1 \%$ & $0.54[0.10,2.87]$ & & & & \\
\hline Knodell 1981 & 1 & 90 & 1 & 85 & $19.2 \%$ & $0.94[0.06,14.86]$ & & & & \\
\hline Polymeropoulos 2015 & 0 & 11 & 0 & 11 & & Not estimable & & & & \\
\hline van Wagoner 2003 & 0 & 177 & 0 & 169 & & Not estimable & & & & \\
\hline Total events & 3 & & 5 & 301 & $71.3 \%$ & $0.03[0.15,2.02]$ & & & & \\
\hline \multicolumn{11}{|c|}{$\begin{array}{l}\text { Heterogeneity: } \text { Tau }^{2}=0.00 ; \mathrm{Chi}^{2}=0.12, \mathrm{df}=1(\mathrm{P}=0.73) ; \mathrm{I}^{2}=0 \% \\
\text { Test for overall effect: } Z=0.64(P=0.52)\end{array}$} \\
\hline \multicolumn{11}{|c|}{ 1.6.2 Vitamin C compared to standard of care } \\
\hline Antonic 2016 & 0 & 52 & 0 & 53 & & Not estimable & & & & \\
\hline Antonic 2017 & 0 & 50 & 1 & 50 & $14.4 \%$ & $0.33[0.01,7.99]$ & & & & \\
\hline Demirag 2001 & 0 & 10 & 0 & 10 & & Not estimable & & & & \\
\hline Donovan 2012 & 1 & 150 & 0 & 154 & $14.3 \%$ & $3.08[0.13,75.00]$ & & & & \\
\hline $\begin{array}{l}\text { Safaei } 2017 \\
\text { Subtotal }(95 \% \mathrm{Cl})\end{array}$ & 0 & $\begin{array}{r}29 \\
291\end{array}$ & 0 & $\begin{array}{r}29 \\
296\end{array}$ & $28.7 \%$ & $\begin{array}{r}\text { Not estimable } \\
\mathbf{1 . 0 1}[0.11,9.58]\end{array}$ & & & & \\
\hline \multicolumn{11}{|c|}{$\begin{array}{l}\text { Heterogeneity: } \mathrm{Tau}^{2}=0.00 ; \mathrm{Chi}^{2}=0.94, \mathrm{df}=1(\mathrm{P}=0.33) ; \mathrm{I}^{2}=0 \% \\
\text { Test for overall effect: } Z=0.01(P=0.99)\end{array}$} \\
\hline Total $(95 \% \mathrm{Cl})$ & & 658 & & 657 & $100.0 \%$ & $0.72[0.21,2.40]$ & & & & \\
\hline Total events & 4 & & 6 & & & & & & & \\
\hline $\begin{array}{l}\text { Heterogeneity: } \operatorname{Tau}^{2}=0 \\
\text { Test for overall effect: } Z \\
\text { Test for subaroun diffe }\end{array}$ & $\begin{array}{l}10 ; \mathrm{Chi}^{2}= \\
0.54(\mathrm{P}= \\
\text { nces: } \mathrm{Chi}\end{array}$ & $\begin{array}{l}1.18, d \\
0.59) \\
y^{2}=0.12\end{array}$ & 2. $d f=3(P=$ & $\begin{array}{l}0.76) ; \\
P=0.7\end{array}$ & $\begin{array}{l}F^{2}=0 \% \\
3{ }^{2}=0 \%\end{array}$ & & 0.01 & $\begin{array}{c}0.1 \\
\text { Favors vitamin } \mathrm{C}\end{array}$ & $\begin{array}{c}10 \\
\text { Favors control }\end{array}$ & 100 \\
\hline
\end{tabular}

Figure 19. Mortality: subgroup analysis-influence of control group. 
A total of 11 studies contributed to the subgroup analysis investigating any possible influence of the control group on the outcome "ICU-LOS", as shown in Figure 20. We found no evidence of a treatment effect between subgroups (test for subgroup differences $\left(\mathrm{Chi}^{2}=0.52, \mathrm{df}=1(p=0.47)\right.$, $\left.\mathrm{I}^{2}=0 \%\right)$.

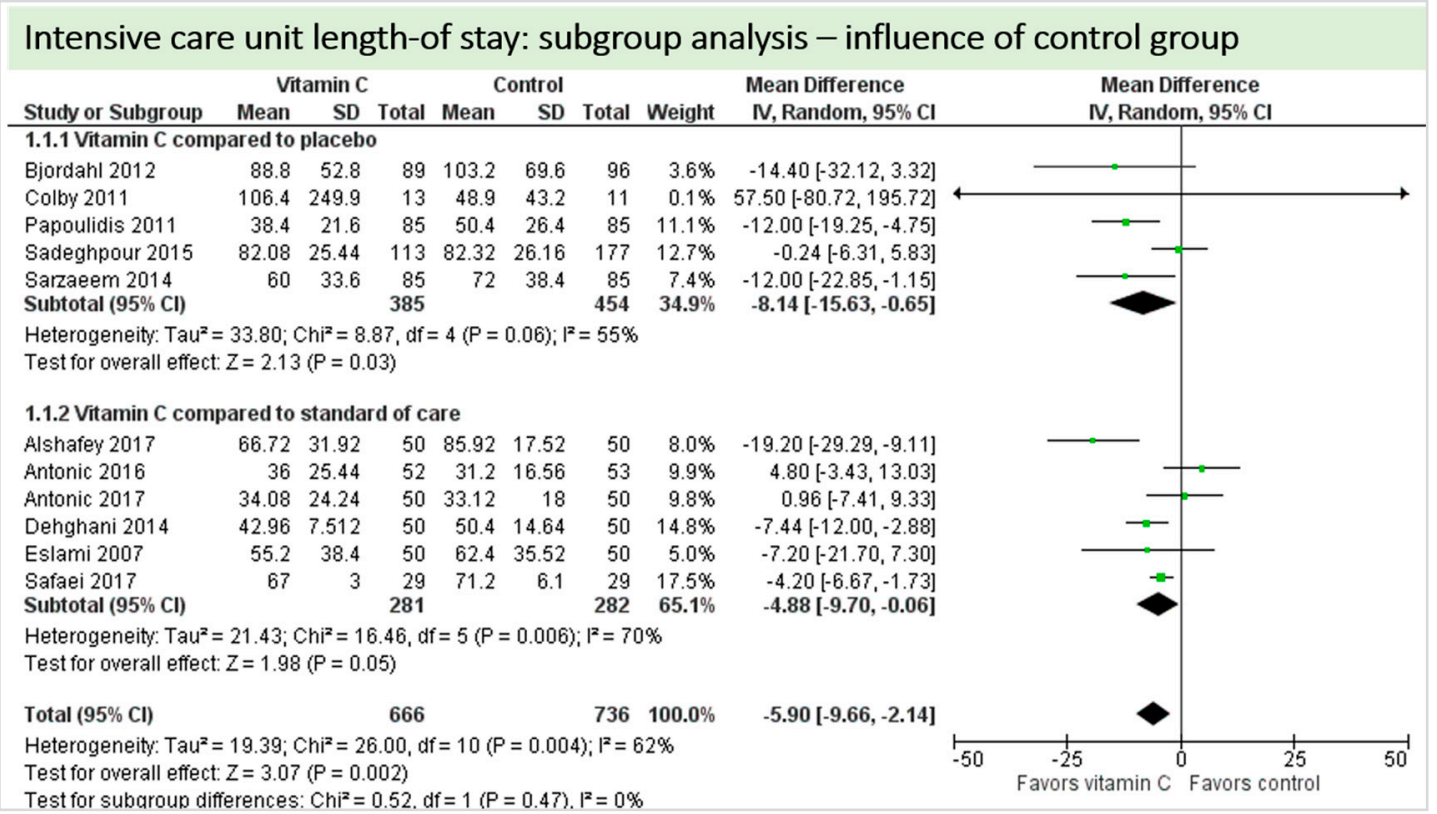

Figure 20. ICU length-of-stay: subgroup analysis-influence of control group.

A total of eight studies contributed to the subgroup analysis investigating any possible influence of the control group on the outcome "hospital-LOS", as shown in Figure 21. We found a statistical significance in the placebo group ( $p<0.00001, \mathrm{CI}-50.48$ to $-29.85, \mathrm{I}^{2}=0 \%$ ). In the standard care group, the treatment effect did not reach statistical significance $\left(p=0.89, \mathrm{CI}-13.90\right.$ to $\left.16.10, \mathrm{I}^{2}=63 \%\right)$. The test for subgroup differences $\left(\mathrm{Chi}^{2}=19.74, \mathrm{df}=1(p<0.00001), \mathrm{I}^{2}=94.9 \%\right)$ shows evidence that the effect of vitamin $C$ is different between the trials compared to the placebo and those that compared to standard of care on the outcome "hospital-LOS".

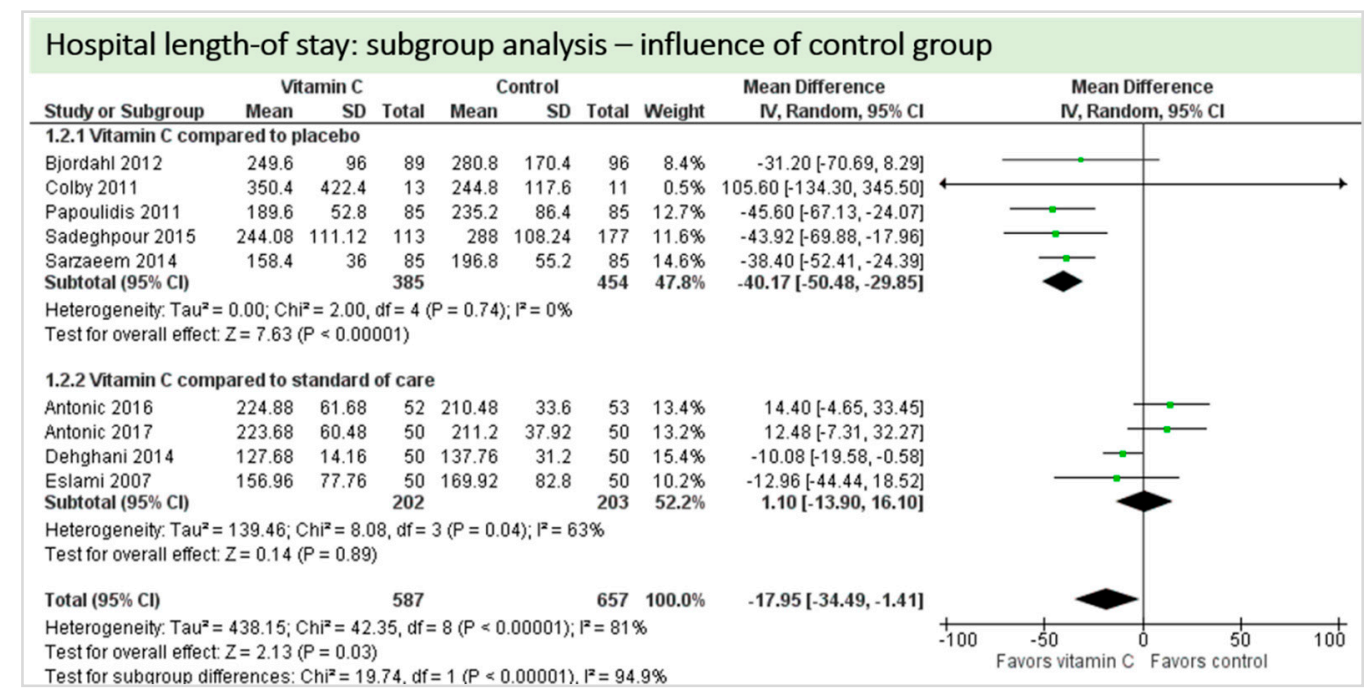

Figure 21. Hospital length of stay: subgroup analysis-influence of control group. 


\subsection{Sensitivity Analysis}

Sensitivity analysis by limiting analyses to studies at low risk of bias for sequence generation, allocation concealment and incomplete outcome data for the primary outcome were not performed, as matching studies did not fulfil the corresponding criteria to allow pooling to make sense.

\section{Discussion}

Nineteen RCTs with 2008 patients, comparing the perioperative administration of vitamin $C$ with placebo or standard of care in adult patients undergoing cardiac surgery, were systematically identified and data were aggregated for meta-analysis where appropriate.

On average, no significant effect of vitamin $C$ was found on in-hospital mortality. Regarding our main outcome-organ dysfunction—vitamin C had no influence on the occurrence of stroke. However, vitamin $C$ significantly decreased the incidence of atrial fibrillation and ventilation time as a marker of pulmonary dysfunction. Various adverse events were reported, but the heterogeneity limited the pooling of data. Regarding renal dysfunction, there were not enough data to pool.

Overall, only few studies reported on postoperative organ dysfunction. Reports were mostly limited to a single disease or surrogate parameter of one organ system, sometimes with very low overall incidences.

\subsection{Quality of the Evidence}

Risk of bias varied across included studies, and insufficient detail was provided to inform judgement in several cases. Three studies were reported as abstracts only, for two studies we had to rely on data from clinical trial registries only, although studies were completed several years ago. We have contacted several authors, sometimes several from one publication, but had a very low response rate to verify key characteristics and missing results of included studies. Especially with regard to random sequence generation and allocation concealment, the majority of studies either did not perform, or did not report both key aspects for selection bias adequately. We regard both measures against selection bias as key principles of RCTs and we want to highlight the importance of improving clinical trial methodology in future trials regarding this aspect-an aim that can be achieved easily with freely accessible and available methods. About blinding of personnel, patients, or outcome assessor, here too, studies have found it difficult to implement this. However, possible effects of these difficulties on performance or detection bias considering the assessed outcome parameters have to be discussed cautiously. We would like to highlight that the applicability of our results should be interpreted based on the described limitations of the quality of the available evidence.

Given the clinical heterogeneity regarding our inclusion criteria (different types of open-heart surgery, different types of vitamin $C$ administration), random-effects meta-analyses were used to produce an overall summary of average treatment effect across trials. The correctness of this decision was reflected by the existence of statistical heterogeneity in the majority of the meta-analyses. Here, heterogeneity in outcome definition, measurement, and reporting limited the possibility to perform meta-analyses and, as a result, the overall quality of the available evidence.

We performed two independent subgroup analyses (subgroup analysis influence of administration route: Intravenous administration versus oral administration of vitamin $C$; and subgroup analysis influence of control group: "vitamin C versus placebo" versus "vitamin C versus standard of care") to explain statistical heterogeneity among study results. With regard to the subgroup analysis influence of administration route, we found evidence of a treatment effect between subgroups for the outcomes "atrial fibrillation, ICU- and hospital-LOS". With regard to the subgroup analysis influence of control group "vitamin C versus placebo" versus "vitamin C versus standard of care", we found evidence of a treatment effect between subgroups for the outcomes "mechanical ventilation and hospital-LOS". The low total number of adverse events as well as the low number of studies contributing to some subgroup analyses (for example "cerebral ischemic events" and "duration of mechanical ventilation") 
limit the conclusions that may be drawn from the meta-analyses. Differences in dosages and route of action of vitamin $C$ when applied intravenously or orally explain the presence of statistical heterogeneity across trials. However, with regard to a possible influence of the control group, the presence of statistical heterogeneity cannot be assessed conclusively.

\subsection{Potential Biases in the Review Process}

We undertook this systematic review in accordance with the Cochrane Handbook for Systematic Reviews of Interventions and followed the guidance of the PRISMA statement for reporting of systematic reviews. We carried out a wide-ranging search across relevant electronic databases and clinical trial registries. We assessed reference lists of included studies and we have described the process of study selection methodically and in full detail. In addition, we screened reference lists of systematic reviews and contacted study authors repeatedly for additional data when needed. We did not apply any language or date restrictions and obtained translations by native speakers. Two review authors performed all steps of the selection process independently and analyses were conducted by one reviewer and checked by a colleague. Furthermore, we gave reasons why a study was not included in our analysis. We described each included study and made explicit judgements about whether studies were at low or high risk of bias. As a result, we identified no other potential sources of bias with regard to the conduct of this systematic review.

\subsection{Agreements and Disagreements with Other Reviews}

The results of our meta-analyses are confirmed by other published meta-analyses investigating the effect of vitamin $C$ in cardiac surgery patients, which mainly focus on the rate of atrial fibrillation. A reduced ICU-LOS was also observed by three meta-analyses focusing exclusively on perioperative vitamin $C$ administration $[11,13,15]$ and one meta-analysis investigating the antioxidant effects of vitamins by Geng et al. [38]. Three meta-analyses also found significantly shorter hospital-LOS associated with vitamin C [11,15,39]. However, Hu et al. performed a meta-analysis where vitamin C administration was not associated with reductions in either ICU-or hospital-LOS [14].

Regarding atrial fibrillation, our results confirm the results of other meta-analyses [12-15], who all found a significant beneficial effect of vitamin C. None of the other meta-analyses assessed organ dysfunctions other than atrial fibrillation, but Shi et al. found significantly fewer adverse events in patients receiving vitamin C [15].

\subsection{Implications for Practice}

Postoperative organ dysfunctions in patients after cardiac surgery are associated with a complicated postoperative course. Despite substantial improvements in the surgical techniques, perfusion, and anesthesiologic management, the incidence and morbidity of patients undergoing cardiac surgery remains high, especially in those patients with combined or complex procedures [40]. This necessitates more effective strategies to counteract the frequently observed inflammatory response, which leads to the development of organ dysfunctions. Among these, the perioperative administration of vitamin $C$ has emerged a promising strategy which has been evaluated in several clinical studies and analyzed in the present meta-analysis. The high heterogeneity between the included RCTs limit this meta-analysis and the applicability for the clinical routine.

While perioperative vitamin $C$ administration seems to be beneficial regarding several outcomes, this meta-analysis cannot answer the question whether vitamin $C$ can prevent single-or multi-organ dysfunction after cardiac surgery.

\subsection{Implications for Research}

Future trials should focus in greater detail on outcomes influencing patient-relevant and long-term outcomes, such as quality of life, organ dysfunction, discharge location, or return-to-work capability. These clinically relevant outcomes, including surrogate parameters of the dysfunction of the different 
organ systems, should be reported in greater detail, as they might be more sensitive to assess the effectivity of antioxidants or other micronutrients.

The heterogeneity observed between trials regarding population, timing, dosage and route of administration, as well as reported outcomes led to difficulties in pooling the data for meta-analysis. This implies the need for the application of core measurement and core outcome sets for micronutrient administration in patients undergoing major surgery.

Both the rather low mortality rates and low incidence of postoperative organ dysfunctions indicated that the majority of studies included evaluated the effects of vitamin $C$ on a rather low-risk group of cardiac surgery patients. In contrast, only few studies were available which focused only on patients with complex procedures and resulting prolonged ICU-LOS, which are most vulnerable for postoperative complications and thus of high interest for specific anti-inflammatory strategies, such as vitamin C.

\section{Conclusions}

Vitamin C impacts clinically and economically important outcomes, such as ICU-and hospital length-of-stay, and duration of mechanical ventilation, and lowers the incidence of atrial fibrillation. Due to missing reports on organ dysfunction, this meta-analysis cannot answer the question of whether vitamin C can improve single- or multi-organ function after cardiac surgery. Future RCTs should focus on the selection of a patient group more vulnerable to a prolonged ICU stay, as well as on careful reports on clinically-and patient-relevant outcomes.

Author Contributions: A.H. and C.B. equally contributed to the conception and design of the research together with S.W., C.S. and D.K.H. A.H. and C.B. drafted the manuscript together with C.S., S.W. and N.A. Figures were provided by A.H. and C.B. A.H., C.B., S.W., K.C.C., A.G.M., C.S. and D.K.H. contributed to the acquisition of data and to the study selection. C.B. and A.H. performed the meta-analysis with A.G.M., K.C.C. and N.A. All authors contributed to analysis and interpretation of the reviewed data, critically revised the manuscript, agree to be fully accountable for ensuring the integrity and accuracy of the work, and read and approved the final manuscript. A.H. and C.B. are the guarantors for this review and meta-analysis.

Acknowledgments: The project was supported by the "clinician scientist program" of the Faculty of Medicine of the RWTH Aachen University (A.H.). No funding was received for this review. We thank Erfan Taheri (M.D) for his translation of the full text Farsi publication.

Conflicts of Interest: The authors declare no conflict of interest that may be perceived as inappropriately influencing the representation or interpretation of reported research results.

\section{Abbreviations}

$\begin{array}{ll}\text { CABG } & \text { Coronary Artery Bypass Graft } \\ \text { CPB } & \text { Cardiopulmonary bypass } \\ \text { CI } & \text { Confidence interval } \\ \text { GSE } & \text { Grape seed extract } \\ \text { ICU } & \text { Intensive care unit } \\ \text { LOS } & \text { Length of stay } \\ \text { n.a. } & \text { Not available } \\ \text { p.o. } & \text { Per os/orally } \\ \text { Postop } & \text { After surgery } \\ \text { Preop } & \text { Before surgery } \\ \text { RCT } & \text { Randomized controlled trial } \\ \text { Vit C } & \text { Vitamin C }\end{array}$




\section{Appendix A. Manuscripts Excluded from this Analysis after Full Text Screening}

\begin{tabular}{|c|c|c|}
\hline & Author and Year & Rationale for Exclusion \\
\hline 1 & Ali-Hasan Al Saegh 2016 [41] & Systematic review and meta-analysis \\
\hline 2 & Ali-Hassan-Sayegh 2014 [39] & Systematic review and meta-analysis \\
\hline 3 & Baines 2002 [42] & Review \\
\hline 4 & Baker 2016 [11] & Meta-analysis \\
\hline 5 & Carnes 2001 [43] & No randomization and retrospective control group \\
\hline 6 & Das 2016 [44] & Use of inappropriate medication in control group (antacid instead of placebo) \\
\hline 7 & Dingchao 1994 [45] & No randomization, "divided into two groups" \\
\hline 8 & Ebade 2014 [46] & No randomization, "divided into three equal groups" \\
\hline 9 & Hemilae 2017 [13] & Systematic review and meta-analysis \\
\hline 10 & Hill 2018 [4] & Review \\
\hline 11 & Нu 2017 [14] & Meta-analysis \\
\hline 12 & Kumar 2013 [47] & Meta-analysis \\
\hline 13 & Li 1990 [48] & $\begin{array}{l}\text { Randomization strategy not mentioned in abstract. } \\
\text { Full text not accessible, attempts to contact author unsuccessful. }\end{array}$ \\
\hline 14 & Liu 2010 [49] & Letter to the editor \\
\hline 15 & Moludi 2016 [50] & $\begin{array}{l}\text { Paper and abstract within the university's journal, abstract identical to included } \\
\text { publiction by Sadeghpour et al. [19] }\end{array}$ \\
\hline 16 & Oktar $2001[51]$ & No randomization \\
\hline 17 & Oudemans-van Straten [7] & Review \\
\hline 18 & Polymeropoulos 2016 [12] & Meta-analysis \\
\hline 19 & Rasoli 2011 [52] & Review \\
\hline 20 & Rodrigo 2008 [53] & Review \\
\hline 21 & Rodrigo 2009 [54] & Review \\
\hline 22 & Rebrova [55] & No randomization \\
\hline 23 & Sisto 1995 [56] & Inappropriate comedication (allopurinol) \\
\hline 24 & Samadikah 2014 [57] & Inappropriate comedication (statin) \\
\hline 25 & Shi 2018 [15] & Meta-analysis \\
\hline 26 & NCT00519337 & Registered trial on clinicaltrials.gov, no results posted or found \\
\hline 28 & NCT01167569 & $\begin{array}{l}\text { Registered trial on clinicaltrials.gov. Contact to author unsuccessful, } \\
\text { no results posted or found }\end{array}$ \\
\hline
\end{tabular}

\section{Appendix B. Methods for Risk of Bias Assessment}

\section{B.1. Selection Bias}

For each included study, we described the method used to generate the allocation sequence in sufficient detail to allow an assessment of whether it should produce comparable groups. The method was assessed as follows:

- $\quad$ Low risk (any truly random process, e.g., random number table; computer random number generator);

- High risk (any non-random process, e.g., odd or even date of birth; hospital or clinic record number);

- Unclear risk (insufficient information to permit judgement).

\section{B.2. Allocation Concealment}

For each included study, we described the method used to conceal the allocation sequence and determine whether the intervention allocation could have been foreseen in advance of or during recruitment, or changed after assignment. We assessed the method as follows:

- $\quad$ Low risk (e.g., telephone or central randomization; consecutively numbered, sealed, opaque envelopes);

- High risk (open random allocation; unsealed or non-opaque envelopes; alternation; date of birth);

- Unclear risk (insufficient information to permit judgement).

\section{B.3. Performance Bias}

We described whether participants and personnel were blind to the allocation to the intervention or control groups in our 'Risk of bias' assessment. We assessed the methods as:

- Low, high or unclear risk of bias for participants;

- Low, high or unclear risk of bias for personnel. 


\section{B.4. Detection Bias}

For each study included, we described the methods used, if any, to blind outcome assessors from knowledge of which intervention a participant received. We considered studies to be at low risk of bias if they were blinded or if we judged that the lack of blinding could not have affected the results. We assessed the method as follows:

- Low risk (no blinding of outcome assessment but the authors judged that the outcome was not likely to be influenced by this);

- High risk (no blinding of outcome assessment and the outcome measurement was likely to have been influenced by this);

- $\quad$ Unclear risk (insufficient information to permit judgement; the study did not address this).

\section{B.5. Attrition Bias}

For each included study and for each outcome or class of outcomes, we described the completeness of data including attrition and exclusions from the analysis. We state whether attrition and exclusions were reported, the numbers included in the analysis at each stage (compared with the total number of randomized participants), reasons for attrition or exclusion where reported, and whether missing data are balanced across groups or are related to outcomes. We assessed the method as follows:

- $\quad$ Low risk (20\% or less missing data);

- High risk (more than $20 \%$ missing data);

- Unclear risk (insufficient reporting to permit judgement; the study did not address this).

\section{B.6. Reporting Bias}

Selective reporting (checking for reporting bias): we investigated the possibility of selective outcome reporting bias by identifying the outcomes in the study protocol (if available) and in the methods section of the publication, and by crosschecking to see if these outcomes were reported in the results section of the trial publication(s). We assessed the method as follows:

- Low risk (where it was clear that all of the study's prespecified outcomes as identified in the study protocol (where available) and in the methods section were reported on; that all expected outcomes of interest to the review were reported on);

- High risk (where it was clear that not all of the study's prespecified outcomes as identified in the study protocol (where available) and in the methods section were reported on; failure to include a key outcome that would have been expected to have been included);

- Unclear risk (insufficient information to permit judgement).

\section{B.7. Other Bias}

For each included study, we described any important concerns we had about other possible sources of bias, for example sources of research funding. We assessed whether each study was free of other problems that could put it at risk of bias as follows:

- $\quad$ Low risk (study appeared to be free of bias);

- High risk (had at least one important risk of bias, for example related to study design);

- Unclear risk (insufficient information to permit judgement).

\section{Appendix C. Risk of Bias Assessment}

Alshafey 2017

\begin{tabular}{|l|l|l|}
\hline Bias & Authors' judgement & Support for judgement \\
\hline $\begin{array}{l}\text { Random sequence generation } \\
\text { (selection bias) }\end{array}$ & Unclear risk & Insufficient information to form judgement \\
\hline $\begin{array}{l}\text { Allocation concealment } \\
\text { (selection bias) }\end{array}$ & Unclear risk & Insufficient information to form judgement \\
\hline $\begin{array}{l}\text { Blinding of participants and personnel } \\
\text { (performance bias) }\end{array}$ & High risk & No blinding of participants and personnel \\
\hline $\begin{array}{l}\text { Blinding of outcome assessment } \\
\text { (detection bias) }\end{array}$ & High risk & No blinding of outcome assessment \\
\hline $\begin{array}{l}\text { Incomplete outcome data } \\
\text { (attrition bias) }\end{array}$ & Low risk & All data reported \\
\hline Selective reporting (reporting bias) & Unclear risk & $\begin{array}{l}\text { All outcomes stated in the methods section were } \\
\text { adequately reported or explained in results }\end{array}$ \\
\hline Other bias & Unclear risk & $\begin{array}{l}\text { Funding for trial: not reported } \\
\text { Notable conflicts of interest of authors: not reported }\end{array}$ \\
\hline
\end{tabular}


Antonic 2016

\begin{tabular}{|l|l|l|}
\hline Bias & Authors' judgement & Support for judgement \\
\hline $\begin{array}{l}\text { Random sequence generation } \\
\text { (selection bias) }\end{array}$ & Unclear risk & Insufficient information to form judgement \\
\hline $\begin{array}{l}\text { Allocation concealment } \\
\text { (selection bias) }\end{array}$ & Unclear risk & Insufficient information to form judgement \\
\hline $\begin{array}{l}\text { Blinding of participants and personnel } \\
\text { (performance bias) }\end{array}$ & High risk & No blinding of participants and personnel \\
\hline $\begin{array}{l}\text { Blinding of outcome assessment } \\
\text { (detection bias) }\end{array}$ & High risk & No blinding of outcome assessment \\
\hline $\begin{array}{l}\text { Incomplete outcome data } \\
\text { (attrition bias) }\end{array}$ & Low risk & All data reported \\
\hline Selective reporting (reporting bias) & Low risk & $\begin{array}{l}\text { All outcomes stated in the methods section were } \\
\text { adequately reported or explained in results }\end{array}$ \\
\hline Other bias & Low risk & $\begin{array}{l}\text { Funding for trial: no funding } \\
\text { Notable conflicts of interest of authors: all authors } \\
\text { declare no conflict of interest }\end{array}$ \\
\hline
\end{tabular}

Antonic 2017

\begin{tabular}{|l|l|l|}
\hline Bias & Authors' judgement & Support for judgement \\
\hline $\begin{array}{l}\text { Random sequence generation } \\
\text { (selection bias) }\end{array}$ & Unclear risk & Insufficient information to form judgement \\
\hline $\begin{array}{l}\text { Allocation concealment } \\
\text { (selection bias) }\end{array}$ & Unclear risk & Insufficient information to form judgement \\
\hline $\begin{array}{l}\text { Blinding of participants and personnel } \\
\text { (performance bias) }\end{array}$ & High risk & No blinding of participants and personnel \\
\hline $\begin{array}{l}\text { Blinding of outcome assessment } \\
\text { (detection bias) }\end{array}$ & High risk & No blinding of outcome assessment \\
\hline $\begin{array}{l}\text { Incomplete outcome data } \\
\text { (attrition bias) }\end{array}$ & Low risk & All data reported \\
\hline Selective reporting (reporting bias) & Low risk & $\begin{array}{l}\text { All outcomes stated in the methods section were } \\
\text { adequately reported or explained in results }\end{array}$ \\
\hline Other bias & Unclear risk & $\begin{array}{l}\text { Funding for trial: not reported } \\
\text { Notable conflicts of interest of authors: not reported }\end{array}$ \\
\hline
\end{tabular}

\section{Bakr 2015}

\begin{tabular}{|l|l|l|}
\hline Bias & Authors' judgement & Support for judgement \\
\hline $\begin{array}{l}\text { Random sequence generation } \\
\text { (selection bias) }\end{array}$ & Unclear risk & Insufficient information to form judgement \\
\hline $\begin{array}{l}\text { Allocation concealment } \\
\text { (selection bias) }\end{array}$ & Unclear risk & Insufficient information to form judgement \\
\hline $\begin{array}{l}\text { Blinding of participants and personnel } \\
\text { (performance bias) }\end{array}$ & Unclear risk & Insufficient information to form judgement \\
\hline $\begin{array}{l}\text { Blinding of outcome assessment } \\
\text { (detection bias) }\end{array}$ & Unclear risk & Insufficient information to form judgement \\
\hline $\begin{array}{l}\text { Incomplete outcome data } \\
\text { (attrition bias) }\end{array}$ & Unclear risk & Insufficient information to form judgement \\
\hline Selective reporting (reporting bias) & Unclear risk & Insufficient information to form judgement \\
\hline Other bias & Unclear risk & $\begin{array}{l}\text { Funding for trial: not reported } \\
\text { Notable conflicts of interest of authors: not reported }\end{array}$ \\
\hline
\end{tabular}


Bjordahl 2012

\begin{tabular}{|c|c|c|}
\hline Bias & Authors' judgement & Support for judgement \\
\hline $\begin{array}{l}\text { Random sequence generation } \\
\text { (selection bias) }\end{array}$ & Unclear risk & Insufficient information to form judgement \\
\hline $\begin{array}{l}\text { Allocation concealment } \\
\text { (selection bias) }\end{array}$ & Low risk & $\begin{array}{l}\text { "The pharmacy department maintained the } \\
\text { randomization list andassigned participants to the } \\
{[\ldots] \text { arms of the study in a blinded fashion." }}\end{array}$ \\
\hline $\begin{array}{l}\text { Blinding of participants and personnel } \\
\text { (performance bias) }\end{array}$ & Low risk & $\begin{array}{l}\text { "Participants, clinicians, and evaluators were } \\
\text { blinded to the treatment assignments and the blind } \\
\text { was not broken until after data analyses were } \\
\text { complete." }\end{array}$ \\
\hline $\begin{array}{l}\text { Blinding of outcome assessment } \\
\text { (detection bias) }\end{array}$ & Low risk & $\begin{array}{l}\text { "[ ... ] evaluators were blinded to the treatment } \\
\text { assignments and the blind was not broken until } \\
\text { after data analyses were complete" }\end{array}$ \\
\hline $\begin{array}{l}\text { Incomplete outcome data } \\
\text { (attrition bias) }\end{array}$ & Low risk & All data reported \\
\hline Selective reporting (reporting bias) & Low risk & $\begin{array}{l}\text { All outcomes stated in the methods section were } \\
\text { adequately reported or explained in results }\end{array}$ \\
\hline Other bias & Low risk & $\begin{array}{l}\text { Funding for trial: not reported } \\
\text { Notable conflicts of interest of authors: all authors } \\
\text { report no conflict of interest }\end{array}$ \\
\hline
\end{tabular}

\section{Colby 2011}

\begin{tabular}{|c|c|c|}
\hline Bias & Authors' judgement & Support for judgement \\
\hline $\begin{array}{l}\text { Random sequence generation } \\
\text { (selection bias) }\end{array}$ & Low risk & $\begin{array}{l}\text { "Eligible patients were randomized using a } \\
\text { computer-generated sequence with a 1:1 allocation } \\
\text { and a random block size of } 10 . "\end{array}$ \\
\hline $\begin{array}{l}\text { Allocation concealment } \\
\text { (selection bias) }\end{array}$ & Low risk & $\begin{array}{l}\text { "Eligible patients were randomized using a } \\
\text { computer-generated sequence with a 1:1 allocation } \\
\text { and a random block size of 10." }\end{array}$ \\
\hline $\begin{array}{l}\text { Blinding of participants and personnel } \\
\text { (performance bias) }\end{array}$ & Low risk & $\begin{array}{l}\text { "Study patients, cardiothoracic surgeons, } \\
\text { caregivers, and investigators, including those } \\
\text { responsible for data collection, were blinded to the } \\
\text { treatment allocation." }\end{array}$ \\
\hline $\begin{array}{l}\text { Blinding of outcome assessment } \\
\text { (detection bias) }\end{array}$ & Low risk & $\begin{array}{l}\text { "Study patients, cardiothoracic surgeons, } \\
\text { caregivers, and investigators, including those } \\
\text { responsible for data collection, were blinded to the } \\
\text { treatment allocation." }\end{array}$ \\
\hline $\begin{array}{l}\text { Incomplete outcome data } \\
\text { (attrition bias) }\end{array}$ & Low risk & $\begin{array}{l}\text { All data reported (one patient excluded from } \\
\text { analysis as the patient did not receive the study } \\
\text { drug) }\end{array}$ \\
\hline Selective reporting (reporting bias) & Low risk & $\begin{array}{l}\text { All outcomes stated in the methods section were } \\
\text { adequately reported or explained in results }\end{array}$ \\
\hline Other bias & Low risk & $\begin{array}{l}\text { Funding for trial: Gustavus and Luise Pfeiffer } \\
\text { Research Foundation, the sponsor played no role in } \\
\text { the design, execution, analysis or submission of the } \\
\text { trial and its results } \\
\text { Notable conflicts of interest of authors: all authors } \\
\text { report no conflict of interest }\end{array}$ \\
\hline
\end{tabular}


Dehghani 2014

\begin{tabular}{|l|l|l|}
\hline Bias & Authors' judgement & Support for judgement \\
\hline $\begin{array}{l}\text { Random sequence generation } \\
\text { (selection bias) }\end{array}$ & Low risk & $\begin{array}{l}\text { "Patients were randomized into two groups in a 1:1 } \\
\text { ratio using random-number table." }\end{array}$ \\
\hline $\begin{array}{l}\text { Allocation concealment } \\
\text { (selection bias) }\end{array}$ & Unclear risk & Insufficient information to form judgement \\
\hline $\begin{array}{l}\text { Blinding of participants and personnel } \\
\text { (performance bias) }\end{array}$ & High risk & No blinding of participants and personnel \\
\hline $\begin{array}{l}\text { Blinding of outcome assessment } \\
\text { (detection bias) }\end{array}$ & High risk & No blinding of outcome assessment \\
\hline $\begin{array}{l}\text { Incomplete outcome data } \\
\text { (attrition bias) }\end{array}$ & Low risk & All data reported \\
\hline Selective reporting (reporting bias) & Low risk & $\begin{array}{l}\text { All outcomes stated in the methods section were } \\
\text { adequately reported or explained in results }\end{array}$ \\
\hline Other bias & $\begin{array}{l}\text { Funding for trial: not reported } \\
\text { Notable conflicts of interest of authors: all authors } \\
\text { report no conflict of interest }\end{array}$ \\
\hline
\end{tabular}

Demirag 2001

\begin{tabular}{|l|l|l|}
\hline Bias & Authors' judgement & Support for judgement \\
\hline $\begin{array}{l}\text { Random sequence generation } \\
\text { (selection bias) }\end{array}$ & Unclear risk & Insufficient information to form judgement \\
\hline $\begin{array}{l}\text { Allocation concealment } \\
\text { (selection bias) }\end{array}$ & Unclear risk & Insufficient information to form judgement \\
\hline $\begin{array}{l}\text { Blinding of participants and personnel } \\
\text { (performance bias) }\end{array}$ & High risk & No blinding of participants and personnel \\
\hline $\begin{array}{l}\text { Blinding of outcome assessment } \\
\text { (detection bias) }\end{array}$ & High risk & No blinding of outcome assessment \\
\hline $\begin{array}{l}\text { Incomplete outcome data } \\
\text { (attrition bias) }\end{array}$ & Low risk & All data reported \\
\hline Selective reporting (reporting bias) & Low risk & $\begin{array}{l}\text { All outcomes stated in the methods section were } \\
\text { adequately reported or explained in results }\end{array}$ \\
\hline Other bias & Unclear risk & $\begin{array}{l}\text { Funding for trial: not reported } \\
\text { Notable conflicts of interest of authors: not reported }\end{array}$ \\
\hline
\end{tabular}

Donovan 2012

\begin{tabular}{|l|l|l|}
\hline Bias & Authors' judgement & Support for judgement \\
\hline $\begin{array}{l}\text { Random sequence generation } \\
\text { (selection bias) }\end{array}$ & Unclear risk & Insufficient information to form judgement \\
\hline $\begin{array}{l}\text { Allocation concealment } \\
\text { (selection bias) }\end{array}$ & Unclear risk & Insufficient information to form judgement \\
\hline $\begin{array}{l}\text { Blinding of participants and personnel } \\
\text { (performance bias) }\end{array}$ & Unclear risk & Insufficient information to form judgement \\
\hline $\begin{array}{l}\text { Blinding of outcome assessment } \\
\text { (detection bias) }\end{array}$ & Unclear risk & Insufficient information to form judgement \\
\hline $\begin{array}{l}\text { Incomplete outcome data } \\
\text { (attrition bias) }\end{array}$ & Unclear risk & Insufficient information to form judgement \\
\hline Selective reporting (reporting bias) & Unclear risk & Insufficient information to form judgement \\
\hline Other bias & Unclear risk & $\begin{array}{l}\text { Funding for trial: not reported } \\
\text { Notable conflicts of interest of authors: not reported }\end{array}$ \\
\hline
\end{tabular}


Eslami 2007

\begin{tabular}{|c|c|c|}
\hline Bias & Authors' judgement & Support for judgement \\
\hline $\begin{array}{l}\text { Random sequence generation } \\
\text { (selection bias) }\end{array}$ & Unclear risk & Insufficient information to form judgement \\
\hline $\begin{array}{l}\text { Allocation concealment } \\
\text { (selection bias) }\end{array}$ & Unclear risk & Insufficient information to form judgement \\
\hline $\begin{array}{l}\text { Blinding of participants and personnel } \\
\text { (performance bias) }\end{array}$ & High risk & No blinding of participants and personnel \\
\hline $\begin{array}{l}\text { Blinding of outcome assessment } \\
\text { (detection bias) }\end{array}$ & Low risk & $\begin{array}{l}\text { "Echocardiography [ ... ] was performed before } \\
\text { surgery by a single investigator in a blinded } \\
\text { fashion." } \\
\text { "All of the Holter recordings were examined by a } \\
\text { single investigator who had been blinded to } \\
\text { patients' group assignments." }\end{array}$ \\
\hline $\begin{array}{l}\text { Incomplete outcome data } \\
\text { (attrition bias) }\end{array}$ & Low risk & All data reported \\
\hline Selective reporting (reporting bias) & Low risk & $\begin{array}{l}\text { All outcomes stated in the methods section were } \\
\text { adequately reported or explained in results }\end{array}$ \\
\hline Other bias & Unclear risk & $\begin{array}{l}\text { Funding for trial: This study was supported in part } \\
\text { by a research grant from Tehran University of } \\
\text { Medical Sciences } \\
\text { Notable conflicts of interest of authors: not reported }\end{array}$ \\
\hline
\end{tabular}

Healy 2010

\begin{tabular}{|l|l|l|}
\hline Bias & Authors' judgement & Support for judgement \\
\hline $\begin{array}{l}\text { Random sequence generation } \\
\text { (selection bias) }\end{array}$ & Unclear risk & Insufficient information to form judgement \\
\hline $\begin{array}{l}\text { Allocation concealment } \\
\text { (selection bias) }\end{array}$ & Unclear risk & Insufficient information to form judgement \\
\hline $\begin{array}{l}\text { Blinding of participants and personnel } \\
\text { (performance bias) }\end{array}$ & High risk & No blinding of participants and personnel \\
\hline $\begin{array}{l}\text { Blinding of outcome assessment } \\
\text { (detection bias) }\end{array}$ & Unclear risk & Insufficient information to form judgement \\
\hline $\begin{array}{l}\text { Incomplete outcome data } \\
\text { (attrition bias) }\end{array}$ & High risk & $\begin{array}{l}\text { Interim analysis of only } 60 \text { patients reported as } \\
\text { abstract only }\end{array}$ \\
\hline Selective reporting (reporting bias) & Unclear risk & Insufficient information to form judgement \\
\hline Other bias & Unclear risk & $\begin{array}{l}\text { Funding for trial: not reported } \\
\text { Notable conflicts of interest of authors: not reported }\end{array}$ \\
\hline
\end{tabular}


Jouybar 2012

\begin{tabular}{|c|c|c|}
\hline Bias & Authors' judgement & Support for judgement \\
\hline $\begin{array}{l}\text { Random sequence generation } \\
\text { (selection bias) }\end{array}$ & Low risk & $\begin{array}{l}\text { "The patients were randomly assigned to two } \\
\text { groups according to the printed table of random } \\
\text { numbers, to either receive }[\ldots] . " \\
\text { "A blinded anesthesiologist who was involved } \\
\text { neither in the patients' allocation and management } \\
\text { nor in the design of the study and data processing } \\
\text { and analysis, generated the randomization list } \\
\text { using a computer program." }\end{array}$ \\
\hline $\begin{array}{l}\text { Allocation concealment } \\
\text { (selection bias) }\end{array}$ & Unclear risk & Insufficient information to form judgement \\
\hline $\begin{array}{l}\text { Blinding of participants and personnel } \\
\text { (performance bias) }\end{array}$ & Unclear risk & $\begin{array}{l}\text { "Moreover, the physician responsible for managing } \\
\text { the patients did not participate in the study." }\end{array}$ \\
\hline $\begin{array}{l}\text { Blinding of outcome assessment } \\
\text { (detection bias) }\end{array}$ & Low risk & $\begin{array}{l}\text { No blinding of outcome assessment, however, only } \\
\text { outcomes were laboratory measures, lack of } \\
\text { blinding has minor impact of evaluation of these } \\
\text { endpoints }\end{array}$ \\
\hline $\begin{array}{l}\text { Incomplete outcome data } \\
\text { (attrition bias) }\end{array}$ & Low risk & $\begin{array}{l}10 \% \text { of patients not treated according to protocol, } \\
\text { excluded from analysis }\end{array}$ \\
\hline Selective reporting (reporting bias) & Unclear risk & $\begin{array}{l}\text { All outcomes stated in the methods section were } \\
\text { adequately reported or explained in results }\end{array}$ \\
\hline Other bias & Low risk & $\begin{array}{l}\text { Funding for trial: This work was supported by } \\
\text { Shiraz University of Medical Sciences } \\
\text { Notable conflicts of interest of authors: all authors } \\
\text { report no conflict of interest }\end{array}$ \\
\hline
\end{tabular}

\begin{tabular}{|c|c|c|}
\hline Bias & Authors' judgement & Support for judgement \\
\hline $\begin{array}{l}\text { Random sequence generation } \\
\text { (selection bias) }\end{array}$ & Unclear risk & Insufficient information to form judgement \\
\hline $\begin{array}{l}\text { Allocation concealment } \\
\text { (selection bias) }\end{array}$ & Unclear risk & Insufficient information to form judgement \\
\hline $\begin{array}{l}\text { Blinding of participants and personnel } \\
\text { (performance bias) }\end{array}$ & Low risk & "double-blind trial" \\
\hline $\begin{array}{l}\text { Blinding of outcome assessment } \\
\text { (detection bias) }\end{array}$ & Low risk & $\begin{array}{l}\text { "Clinical and laboratory data sheets on all patients } \\
\text { with even minor enzyme elevations were } \\
\text { submitted to two independent rereviewers [... ] } \\
\text { for evaluation." } \\
\text { "These reviewers either accepted or rejected } \\
\text { patients as cases of posttransfusion hepatitis, and } \\
\text { analysis of data was based on their decisions." }\end{array}$ \\
\hline $\begin{array}{l}\text { Incomplete outcome data } \\
\text { (attrition bias) }\end{array}$ & High risk & $\begin{array}{l}\text { " } 40 \text { patients [ ... ] who did not complete the study } \\
\text { were distributed equally between the placebo and } \\
\text { vitamin C treatment groups. The vast majority of } \\
\text { patients who did not complete the study either } \\
\text { refused to take the study medication } \\
\text { postoperatively (11 patients in each group) or } \\
\text { refused to have follow-up blood samples drawn." }\end{array}$ \\
\hline Selective reporting (reporting bias) & High risk & $\begin{array}{l}\text { All outcomes stated in the methods section are } \\
\text { NOT adequately reported or explained in results: } \\
\text { Serum aminotransferases (only SGPT, SGOT } \\
\text { missingAlkaline phosphatase missing } \\
\text { Symptoms of congestive heart failure, one month } \\
\text { intervals missing }\end{array}$ \\
\hline Other bias & Unclear risk & $\begin{array}{l}\text { Funding for trial: Hoffmann-LaRoche and the } \\
\text { Veterans Research Service } \\
\text { Notable conflicts of interest of authors: not reported }\end{array}$ \\
\hline
\end{tabular}


Papoulidis 2011

\begin{tabular}{|c|c|c|}
\hline Bias & Authors' judgement & Support for judgement \\
\hline $\begin{array}{l}\text { Random sequence generation } \\
\text { (selection bias) }\end{array}$ & High risk & $\begin{array}{l}\text { "The initial random assignment was by flipping a } \\
\text { coin but simple randomization led to an imbalance } \\
\text { with respect to sample size with a treatment group } \\
\text { of } 130 \text { patients and control group of } 85 \text { patients. In } \\
\text { order to have an equal sample size, we reevaluated } \\
\text { our randomization protocol and using a random } \\
\text { generator, the computer chose } 85 \text { out of } 130 \text { patients } \\
\text { which were initially enrolled in the study group." }\end{array}$ \\
\hline $\begin{array}{l}\text { Allocation concealment } \\
\text { (selection bias) }\end{array}$ & Low risk & $\begin{array}{l}\text { "The initial random assignment was by flipping a } \\
\text { coin but simple randomization led to an imbalance } \\
\text { with respect to sample size with a treatment group } \\
\text { of } 130 \text { patients and control group of } 85 \text { patients. In } \\
\text { order to have an equal sample size, we reevaluated } \\
\text { our randomization protocol and using a random } \\
\text { generator, the computer chose } 85 \text { out of } 130 \text { patients } \\
\text { which were initially enrolled in the study group." }\end{array}$ \\
\hline $\begin{array}{l}\text { Blinding of participants and personnel } \\
\text { (performance bias) }\end{array}$ & High risk & No blinding of participants and personnel \\
\hline $\begin{array}{l}\text { Blinding of outcome assessment } \\
\text { (detection bias) }\end{array}$ & Low risk & $\begin{array}{l}\text { "Echocardiography was performed before surgery } \\
\text { by a single echocardiographer in a blinded } \\
\text { fashion." }\end{array}$ \\
\hline $\begin{array}{l}\text { Incomplete outcome data } \\
\text { (attrition bias) }\end{array}$ & Low risk & All data reported \\
\hline Selective reporting (reporting bias) & Low risk & $\begin{array}{l}\text { All outcomes stated in the methods section were } \\
\text { adequately reported or explained in results }\end{array}$ \\
\hline Other bias & Unclear risk & $\begin{array}{l}\text { Funding for trial: not reported } \\
\text { Notable conflicts of interest of authors: not reported }\end{array}$ \\
\hline
\end{tabular}

Polymeropoulos 2015

\begin{tabular}{|l|l|l|}
\hline Bias & Authors' judgement & Support for judgement \\
\hline $\begin{array}{l}\text { Random sequence generation } \\
\text { (selection bias) }\end{array}$ & Unclear risk & Insufficient information to form judgement \\
\hline $\begin{array}{l}\text { Allocation concealment } \\
\text { (selection bias) }\end{array}$ & Unclear risk & Insufficient information to form judgement \\
\hline $\begin{array}{l}\text { Blinding of participants and personnel } \\
\text { (performance bias) }\end{array}$ & Unclear risk & Insufficient information to form judgement \\
\hline $\begin{array}{l}\text { Blinding of outcome assessment } \\
\text { (detection bias) }\end{array}$ & Unclear risk & Insufficient information to form judgement \\
\hline $\begin{array}{l}\text { Incomplete outcome data } \\
\text { (attrition bias) }\end{array}$ & Low risk & All data reported \\
\hline Selective reporting (reporting bias) & Unclear risk & Insufficient information to form judgement \\
\hline Other bias & Unclear risk & $\begin{array}{l}\text { Funding for trial: not reported } \\
\text { Notable conflicts of interest of authors: not reported }\end{array}$ \\
\hline
\end{tabular}


Sadeghpour 2015

\begin{tabular}{|c|c|c|}
\hline Bias & Authors' judgement & Support for judgement \\
\hline $\begin{array}{l}\text { Random sequence generation } \\
\text { (selection bias) }\end{array}$ & Low risk & $\begin{array}{l}\text { "The study population was randomized one day } \\
\text { before surgery to two groups (by using } \\
\text { www.randomaizer.org). The method of } \\
\text { randomization was balanced block with an } \\
\text { allocation sequence based on a block size of eight, } \\
\text { generated with a computer random number } \\
\text { generator." }\end{array}$ \\
\hline $\begin{array}{l}\text { Allocation concealment } \\
\text { (selection bias) }\end{array}$ & Low risk & $\begin{array}{l}\text { "The study population was randomized one day } \\
\text { before surgery to two groups (by using } \\
\text { www.randomaizer.org). The method of } \\
\text { randomization was balanced block with an } \\
\text { allocation sequence based on a block size of eight, } \\
\text { generated with a computer random number } \\
\text { generator." }\end{array}$ \\
\hline $\begin{array}{l}\text { Blinding of participants and personnel } \\
\text { (performance bias) }\end{array}$ & Low risk & $\begin{array}{l}\text { "Both the patients and the hospital staff were blind } \\
\text { to the treatment allocation." }\end{array}$ \\
\hline $\begin{array}{l}\text { Blinding of outcome assessment } \\
\text { (detection bias) }\end{array}$ & Unclear risk & Insufficient information to form judgement \\
\hline $\begin{array}{l}\text { Incomplete outcome data } \\
\text { (attrition bias) }\end{array}$ & Low risk & All data reported \\
\hline Selective reporting (reporting bias) & Low risk & $\begin{array}{l}\text { All outcomes stated in the methods section were } \\
\text { adequately reported or explained in results }\end{array}$ \\
\hline Other bias & Unclear risk & $\begin{array}{l}\text { Funding for trial: not reported } \\
\text { Notable conflicts of interest of authors: not reported }\end{array}$ \\
\hline
\end{tabular}

\section{Safaei 2017}

\begin{tabular}{|c|c|c|}
\hline Bias & Authors' judgement & Support for judgement \\
\hline $\begin{array}{l}\text { Random sequence generation } \\
\text { (selection bias) }\end{array}$ & Low risk & $\begin{array}{l}\text { "Patients were randomly assigned to three groups } \\
\text { ( } n=29 \text { each) using random allocation software." }\end{array}$ \\
\hline $\begin{array}{l}\text { Allocation concealment } \\
\text { (selection bias) }\end{array}$ & Low risk & $\begin{array}{l}\text { "Patients were randomly assigned to three groups } \\
\text { ( } \mathrm{n}=29 \text { each) using random allocation software." }\end{array}$ \\
\hline $\begin{array}{l}\text { Blinding of participants and personnel } \\
\text { (performance bias) }\end{array}$ & High risk & No blinding of participants and personnel. \\
\hline $\begin{array}{l}\text { Blinding of outcome assessment } \\
\text { (detection bias) }\end{array}$ & Low risk & $\begin{array}{l}\text { "All data were collected by an independent } \\
\text { research nurse assigned to this research study and } \\
\text { were blinded to the groups." } \\
\text { "All clinical data were collected by an independent } \\
\text { end-point assessor team including a cardiologist } \\
\text { and a nurse who were assigned to this clinical trial } \\
\text { and were blinded to group assignment." }\end{array}$ \\
\hline $\begin{array}{l}\text { Incomplete outcome data } \\
\text { (attrition bias) }\end{array}$ & Low risk & Less than $20 \%$ lost to follow-up \\
\hline Selective reporting (reporting bias) & Low risk & $\begin{array}{l}\text { All outcomes stated in the methods section were } \\
\text { adequately reported or explained in results }\end{array}$ \\
\hline Other bias & Unclear risk & $\begin{array}{l}\text { Funding for trial: Cardiovascular Research Center, } \\
\text { Tabriz University of Medical Sciences, Tabriz, Iran } \\
\text { Notable conflicts of interest of authors: all authors } \\
\text { report no conflict of interest }\end{array}$ \\
\hline
\end{tabular}




\begin{tabular}{|l|l|l|}
\hline Sarzaeem 2014 & Authors' judgement & Support for judgement \\
\hline $\begin{array}{l}\text { Bandom sequence generation } \\
\text { (selection bias) }\end{array}$ & Unclear risk & $\begin{array}{l}\text { Insufficient information to form judgement, study } \\
\text { reported in Farsi, translation difficult }\end{array}$ \\
\hline $\begin{array}{l}\text { Allocation concealment } \\
\text { (selection bias) }\end{array}$ & Unclear risk & $\begin{array}{l}\text { Insufficient information to form judgement, study } \\
\text { reported in Farsi, translation difficult }\end{array}$ \\
\hline $\begin{array}{l}\text { Blinding of participants and personnel } \\
\text { (performance bias) }\end{array}$ & Unclear risk & $\begin{array}{l}\text { Insufficient information to form judgement, study } \\
\text { reported in Farsi, translation difficult }\end{array}$ \\
\hline $\begin{array}{l}\text { Blinding of outcome assessment } \\
\text { (detection bias) }\end{array}$ & Unclear risk & $\begin{array}{l}\text { Insufficient information to form judgement, study } \\
\text { reported in Farsi, translation difficult }\end{array}$ \\
\hline $\begin{array}{l}\text { Incomplete outcome data } \\
\text { (attrition bias) }\end{array}$ & Unclear risk & $\begin{array}{l}\text { Insufficient information to form judgement, study } \\
\text { reported in Farsi, translation difficult }\end{array}$ \\
\hline Selective reporting (reporting bias) & Unclear risk & $\begin{array}{l}\text { Insufficient information to form judgement, study } \\
\text { reported in Farsi, translation difficult }\end{array}$ \\
\hline Other bias & Unclear risk & $\begin{array}{l}\text { Insufficient information to form judgement, study } \\
\text { reported in Farsi, translation difficult }\end{array}$ \\
\hline
\end{tabular}

\section{van Wagoner 2003}

\begin{tabular}{|l|l|l|}
\hline Bias & Authors' judgement & Support for judgement \\
\hline $\begin{array}{l}\text { Random sequence generation } \\
\text { (selection bias) }\end{array}$ & Unclear risk & Insufficient information to form judgement \\
\hline $\begin{array}{l}\text { Allocation concealment } \\
\text { (selection bias) }\end{array}$ & Unclear risk & Insufficient information to form judgement \\
\hline $\begin{array}{l}\text { Blinding of participants and personnel } \\
\text { (performance bias) }\end{array}$ & Unclear risk & Insufficient information to form judgement \\
\hline $\begin{array}{l}\text { Blinding of outcome assessment } \\
\text { (detection bias) }\end{array}$ & Unclear risk & Insufficient information to form judgement \\
\hline $\begin{array}{l}\text { Incomplete outcome data } \\
\text { (attrition bias) }\end{array}$ & Unclear risk & Insufficient information to form judgement \\
\hline Selective reporting (reporting bias) & Unclear risk & Insufficient information to form judgement \\
\hline Other bias & Unclear risk & $\begin{array}{l}\text { Funding for trial: not reported } \\
\text { Notable conflicts of interest of authors: all authors } \\
\text { report no conflict of interest }\end{array}$ \\
\hline
\end{tabular}

\section{References}

1. Levy, J.H.; A Tanaka, K. Inflammatory response to cardiopulmonary bypass. Ann. Thorac. Surg. 2003, 75, S715-S720. [CrossRef]

2. Richard, H. Identification of inflammatory mediators and their modulation by strategies for the management of the systemic inflammatory response during cardiac surgery. J. Cardiothorac. Vasc. Anesth. 2013, 27, 983-1033.

3. Landis, R.C.; Brown, J.R.; Fitzgerald, D.; Likosky, N.S.; Shore-Lesserson, L.; Baker, R.A.; Hammon, J.W. Attenuating the Systemic Inflammatory Response to Adult Cardiopulmonary Bypass: A Critical Review of the Evidence Base. J. Extra-Corporeal Technol. 2014, 46, 197-211.

4. Hill, A.; Wendt, S.; Benstoem, C.; Neubauer, C.; Meybohm, P.; Langlois, P.L.; Adhikari, N.K.; Heyland, D.K.; Stoppe, C. Vitamin C to Improve Organ Dysfunction in Cardiac Surgery Patients-Review and Pragmatic Approach. Nutrients 2018, 10, 974. [CrossRef] [PubMed]

5. Stoppe, C.; McDonald, B.; Benstoem, C.; Elke, G.; Meybohm, P.; Whitlock, R.; Fremes, S.E.; Fowler, R.; Lamarche, Y.; Jiang, X.; et al. Evaluation of Persistent Organ Dysfunction Plus Death as a Novel Composite Outcome in Cardiac Surgical Patients. J. Cardiothorac. Vasc. Anesth. 2016, 30, 30-38. [CrossRef] [PubMed]

6. Frei, B.; Stocker, R.; England, L.; Ames, B.N. Ascorbate: The Most Effective Antioxidant in Human Blood Plasma. Vaccine Des. 1990, 264, 155-163. [CrossRef]

7. Straaten, H.O.-V.; Man, A.M.E.S.-D.; De Waard, M.C. Vitamin C revisited. Crit. Care 2014, 18, 460. [CrossRef] 
8. Berger, M.M.; Straaten, H.M.O.-V. Vitamin C supplementation in the critically ill patient. Curr. Opin. Clin. Nutr. Metab. Care 2015, 18, 193-201. [CrossRef]

9. Carr, A.C.; Maggini, S. Vitamin C and Immune Function. Nutrients 2017, 9, 1211. [CrossRef]

10. Man, A.M.E.S.-D.; Elbers, P.; Straaten, H.M.O.-V. Making sense of early high-dose intravenous vitamin C in ischemia/reperfusion injury. Crit. Care 2018, 22, 70. [CrossRef]

11. Baker, W.L.; Coleman, C.I. Meta-analysis of ascorbic acid for prevention of postoperative atrial fibrillation after cardiac surgery. Am. J. Heal. Pharm. 2016, 73, 2056-2066. [CrossRef] [PubMed]

12. Polymeropoulos, E.; Bagos, P.G.; Papadimitriou, M.; Rizos, I.; Patsouris, E.; Toumpoulis, I. Vitamin C for the Prevention of Postoperative Atrial Fibrillation after Cardiac Surgery: A Meta-Analysis. Adv. Pharm. Bull. 2016, 6, 243-250. [CrossRef] [PubMed]

13. Hemilä, H.; Suonsyrjä, T. Vitamin C for preventing atrial fibrillation in high risk patients: A systematic review and meta-analysis. BMC Cardiovasc. Disord. 2017, 17, 49. [CrossRef] [PubMed]

14. Emmanuel, S. Efficacy and safety of vitamin C for atrial fibrillation after cardiac surgery: A meta-analysis with trial sequential analysis of randomized controlled trials. Int. J. Surg. 2017, 37, 125. [CrossRef]

15. Shi, R.; Li, Z.-H.; Chen, D.; Wu, Q.-C.; Zhou, X.-L.; Tie, H. Sole and combined vitamin C supplementation can prevent postoperative atrial fibrillation after cardiac surgery: A systematic review and meta-analysis of randomized controlled trials. Clin. Cardiol. 2018, 41, 871-878. [CrossRef] [PubMed]

16. Cochrane Handbook of Systematic Reviews of Interventions. Version 5.1.0 [updated March 2011]. Available online: http://handbook.cochrane.org/ (accessed on 11 November 2012).

17. Deeks, J.J.; Higgins, J.P.T.; Altman, D.G. Analysing data and undertaking meta-analyses. In Cochrane Handbook for Systematic Reviews of Interventions; The Cochrane Collaboration; John Wiley \& Sons Ltd: Hoboken, NJ, USA, 2008; pp. 243-296. [CrossRef]

18. Higgins, J.P.T.; Thompson, S.G.; Deeks, J.; Altman, U.G. Measuring inconsistency in meta-analyses. BMJ 2003, 327, 557-560. [CrossRef]

19. Sadeghpour, A.; Alizadehasl, A.; Kyavar, M.; Sadeghi, T.; Moludi, J.; Gholizadeh, F.; Totonchi, Z.; Ghadrdoost, B. Impact of Vitamin C Supplementation on Post-Cardiac Surgery ICU and Hospital Length of Stay. Anesthesiol. Pain Med. 2015, 5, 25337. [CrossRef]

20. Alshafey, M.K.; Elrakhawy, H.M.; Rezk, M.E.; Moustafa, H.M. Role of ascorbic acid in reduction of the incidence of the atrial fibrillation in patients under B-blocker and undergoing coronary artery bypass graft operation in early post-operative period. J. Egypt. Soc. Cardio-Thoracic Surg. 2017, 25, 198-203. [CrossRef]

21. Bakr, H.; Elsayegh, T.; El Fatah, M.A. 2. Role of ascorbic acid \& statin in reduction of the incidence of the atrial fibrillation in patients under B-blocker and undergoing coronary artery bypass graft operation in early post-operative period. J. Saudi Hear. Assoc. 2015, 27, 299-300. [CrossRef]

22. Healy, R.M.; Day, D.; van Gorder, C. Ascorbic acid utilization for atrial-fibrillation prophylaxis post coronary-artery-bypass graft and valve replacement surgeries: An interim analysis of a prospective, randomized study. Pharmacotherapy 2010, 30, 445e-446e.

23. Van Wagoner, D.R.; Palumbo, R.; Li, J.; Carnes, C.A.; Gillinov, A.; McCarthy, P.M.; Chung, M.K. Supplemental vitamin $\mathrm{c}$ did not reduce the incidence of atrial arrhythmia following cardiac bypass surgery. Heart Rhythm Soc. 2003. Available online: http://www.mv.helsinki.fi/home/hemila/CAF/vanWagoner2003.pdf (accessed on 4 December 2016).

24. Antonic, M.; Lipovec, R.; Gregorcic, F.; Juric, P.; Kosir, G. Perioperative ascorbic acid supplementation does not reduce the incidence of postoperative atrial fibrillation in on-pump coronary artery bypass graft patients. J. Cardiol. 2017, 69, 98-102. [CrossRef] [PubMed]

25. Antonic, M. Effect of Ascorbic Acid on Postoperative Acute Kidney Injury in Coronary Artery Bypass Graft Patients: A Pilot Study. Hear. Surg. Forum 2017, 20, 214. [CrossRef] [PubMed]

26. Bjordahl, P.M.; Helmer, S.; Gosnell, D.J.; Wemmer, G.E.; O'Hara, W.W.; Milfeld, D.J. Perioperative supplementation with ascorbic acid does not prevent atrial fibrillation in coronary artery bypass graft patients. Am. J. Surg. 2012, 204, 862-867. [CrossRef]

27. Colby, J.A.; Chen, W.T.; Baker, W.L.; Coleman, C.I.; Reinhart, K.; Kluger, J.; White, C.M. Effect of ascorbic acid on inflammatory markers after cardiothoracic surgery. Am. J. Heal. Pharm. 2011, 68, 1632-1639. [CrossRef]

28. Dehghani, M.R.; Madjidi, N.; Rahmani, A.; Askari, B.; Rezaei, Y. Effect of oral vitamin C on atrial fibrillation development after isolated coronary artery bypass grafting surgery: A prospective randomized clinical trial. Cardiol. J. 2014, 21, 492-499. [CrossRef] 
29. Demirag, K.; Askar, F.Z.; Uyar, M.; Cevik, A.; Ozmen, D.; Mutaf, I.; Bayindir, O. The protective effects of high dose ascorbic acid and diltiazem on myocardial ischaemia-reperfusion injury. Middle East J. Anaesthesiol. 2001, 16, 67-79.

30. Donovan, P.C.; Kramer, R.S. Prophylaxis to Reduce Postoperative Atrial Fibrillation in Cardiac Surgery, NCT00953212. Available online: https://linicaltrials.gov/ct2/show/NCT00953212 (accessed on 23 November 2018).

31. Eslami, M.; Badkoubeh, R.S.; Mousavi, M.; Radmehr, H.; Salehi, M.; Tavakoli, N.; Avadi, M.R. Oral Ascorbic Acid in Combination with Beta-Blockers Is More Effective than Beta-Blockers Alone in the Prevention of Atrial Fibrillation after Coronary Artery Bypass Grafting. Tex. Hear. Inst. J. 2007, 34, 268-274.

32. Jouybar, R.; Kabgani, H.; Kamalipour, H.; Shahbazi, S.; Allahyary, E.; Rasouli, M.; Akhlagh, S.H.; Shafa, M.; Ghazinoor, M.; Moeinvaziri, M.T.; et al. The perioperative effect of ascorbic acid on inflammatory response in coronary artery bypass graft surgery; a randomized controlled trial coronary artery bypass graft surgery. Int. Cardiovasc. Res. J. 2012, 6, 13-17.

33. Knodell, R.G.; Tate, M.A.; Akl, B.F.; Wilson, J.W. Vitamin C prophylaxis for posttransfusion hepatitis: Lack of effect in a controlled trial. Am. J. Clin. Nutr. 1981, 34, 20-23. [CrossRef]

34. Papoulidis, P.; Ananiadou, O.; Chalvatzoulis, E.; Ampatzidou, F.; Koutsogiannidis, C.; Karaiskos, T.; Madesis, A.; Drossos, G. The role of ascorbic acid in the prevention of atrial fibrillation after elective on-pump myocardial revascularization surgery: A single-center experience-A pilot study. Interact. Cardiovasc. Thorac. Surg. 2011, 12, 121-124. [CrossRef] [PubMed]

35. Polymeropoulos, E. Vitamin C for Prophylaxis of Post-Operative Atrial Fibrillation in On-Pump Cardiac Surgery Procedures, NCT01107730. Available online: https://clinicaltrials.gov/ct2/show/NCT00953212 (accessed on 23 November 2018).

36. Babaei, H.; Safaie, N.; Azarfarin, R.; Jodati, A.; Yaghoubi, A.; Sheikhalizadeh, M.-A. Comparative effect of grape seed extract (Vitis vinifera) and ascorbic acid in oxidative stress induced by on-pump coronary artery bypass surgery. Ann. Card. Anaesth. 2017, 20, 45-51. [CrossRef] [PubMed]

37. Sarzaeem, M.; Shayan, N. Vitamin c in prevention of atrial fibrillation after coronary artery bypass graft: Double blind randomized clinical trial. Tehran Univ. Med. J. 2014, 71, 2014.

38. Geng, J.; Qian, J.; Si, W.; Cheng, H.; Ji, F.; Shen, Z. The clinical benefits of perioperative antioxidant vitamin therapy in patients undergoing cardiac surgery: A meta-analysis. Interact. Cardiovasc. Thorac. Surg. 2017, 25, 966-974. [CrossRef] [PubMed]

39. Ali-Hassan-Sayegh, S.; Mirhosseini, S.J.; Rezaeisadrabadi, M.; Dehghan, H.; Sedaghat-Hamedani, F.; Kayvanpour, E.; Popov, A.-F.; Liakopoulos, O.J. Antioxidant supplementations for prevention of atrial fibrillation after cardiac surgery: An updated comprehensive systematic review and meta-analysis of 23 randomized controlled trials. Interact. Cardiovasc. Thorac. Surg. 2014, 18, 646-654. [CrossRef]

40. Stoppe, C.; Ney, J.; Lomivorotov, V.V.; Efremov, S.M.; Benstoem, C.; Hill, A.; Nesterova, E.; Laaf, E.; Goetzenich, A.; McDonald, B.; et al. Prediction of Prolonged ICU Stay in Cardiac Surgery Patients as a Useful Method to Identify Nutrition Risk in Cardiac Surgery Patients: A Post Hoc Analysis of a Prospective Observational Study. J. Parenter. Enter. Nutr. 2018, 43, 768-779. [CrossRef]

41. Ali-Hassan-Sayegh, S.; Mirhosseini, S.J.; Tahernejad, M.; Mahdavi, P.; Shahidzadeh, A.; Karimi-Bondarabadi, A.A.; Dehghan, A.-M.; Rahimizadeh, E.; Haddad, F.; Ghodratipour, Z.; et al. Impact of antioxidant supplementations on cardio-renal protection in cardiac surgery: An updated and comprehensive meta-analysis and systematic review. Cardiovasc. Ther. 2016, 34, 360-370. [CrossRef]

42. Baines, M.; Shenkin, A. Use of antioxidants in surgery: A measure to reduce postoperative complications. Curr. Opin. Clin. Nutr. Metab. Care 2002, 5, 665-670. [CrossRef]

43. A Carnes, C.; Chung, M.K.; Nakayama, T.; Nakayama, H.; Baliga, R.S.; Piao, S.; Kanderian, A.; Pavia, S.; Hamlin, R.L.; McCarthy, P.M.; et al. Ascorbate attenuates atrial pacing-induced peroxynitrite formation and electrical remodeling and decreases the incidence of postoperative atrial fibrillation. Circ. Res. 2001, 89, e32-e38. [CrossRef]

44. Das, D.; Sen, C.; Goswami, A. Effect of Vitamin C on adrenal suppression by etomidate induction in patients undergoing cardiac surgery: A randomized controlled trial. Ann. Card. Anaesth. 2016, 19, 410-417. [CrossRef] 
45. Dingchao, H.; ZhiDuan, Q.; Liye, H.; Xiaodong, F. The Protective Effects of High-Dose Ascorbic Acid on Myocardium against Reperfusion Injury During and After Cardiopulmonary Bypass. Thorac. Cardiovasc. Surg. 1994, 42, 276-278. [CrossRef] [PubMed]

46. Ebade, A.; Taha, W.; Saleh, R.; Fawzy, A. Ascorbic acid versus magnesium for the prevention of atrial fibrillation after coronary artery bypass grafting surgery. Egypt. J. Cardiothorac. Anesthesia 2014, 8, 59. [CrossRef]

47. Kumar, S.; Benjo, A.M.; Pamidimukala, C.K.; Javed, F.; Garcia, W.; Macedo, F.Y.; Garcia, D.C.; Santana, O.; Nascimeto, F.O.; Pierce, M.; et al. Vitamin c decreases atrial fibrillation in cardiac surgery patients but vitamin e may decrease response: A randomized-controlled trial meta-analysis. Circ. Cardiovasc. Qual. Outcomes 2013, 6, 288.

48. Li, C.C. Changes of creatine phosphokinase and malondialdehyde in the serum and clinical use of large doses of vitamin C following open heart surgery. Chin. J. Surg 1990, 28, 16-17. [PubMed]

49. Liu, T.; Li, G. Antioxidant interventions as novel preventive strategies for postoperative atrial fibrillation. Int. J. Cardiol. 2009, 145, 140-142. [CrossRef] [PubMed]

50. Moludi, J.; Keshavarz, S.; Pakzad, R.; Sedghi, N.; Sadeghi, T.; Alimoradi, F. Effect of vitamin c supplementation in the prevention of atrial fibrillation. Tehran Univ. Med. J. 2016, 73, 791-797.

51. Oktar, G.L.; Sinci, V.; Kalaycioğlu, S.; Soncul, H.; Gökgöz, L.; Halit, V.; Ersöz, A. Biochemical and hemodynamic effects of ascorbic acid and alpha-tocopherol in coronary artery surgery. Scand. J. Clin. Lab. Investig. 2001, 61, 621-629. [CrossRef]

52. Rasoli, S.; Kourliouros, A.; Harling, L.; Athanasiou, T. Does prophylactic therapy with antioxidant vitamins have an effect on atrial fibrillation following cardiac surgery? Interact. Cardiovasc. Thorac. Surg. 2011, 13, 82-85. [CrossRef]

53. Rodrigo, R.; Cereceda, M.; Castillo, R.; Asenjo, R.; Zamorano, J.; Araya, J.; Castillo-Koch, R.; Espinoza, J.; Larraín, E. Prevention of atrial fibrillation following cardiac surgery: Basis for a novel therapeutic strategy based on non-hypoxic myocardial preconditioning. Pharmacol. Ther. 2008, 118, 104-127. [CrossRef]

54. Rodrigo, R.; Vinay, J.; Castillo, R.; Cereceda, M.; Asenjo, R.; Zamorano, J.; Araya, J.; Castillo-Koch, R.; Espinoza, J.; Larraín, E. Use of vitamins $\mathrm{C}$ and $\mathrm{E}$ as a prophylactic therapy to prevent postoperative atrial fibrillation. Int. J. Cardiol. 2010, 138, 221-228. [CrossRef]

55. Rebrova, T.I.; Shipulin, V.M.; Afanas'ev, S.A.; Vorob'Eva, E.V.; Kirko, O.G. The experience of the application of ascorbinic acid as antioxidant after coronary artery surgery with use of cardiopulmonary bypass. Kardiologiia 2012, 52, 73-76. [PubMed]

56. Sisto, T.; Paajanen, H.; Metsä-Ketelä, T.; Harmoinen, A.; Nordback, I.; Tarkka, M. Pretreatment with antioxidants and allopurinol diminishes cardiac onset events in coronary artery bypass grafting. Ann. Thorac. Surg. 1995, 59, 1519-1523. [CrossRef]

57. Samadikhah, J.; Golzari, S.E.; Sabermarouf, B.; Karimzadeh, I.; Tizro, P.; Khanli, H.M.; Ghabili, K. Efficacy of Combination Therapy of Statin and Vitamin C in Comparison with Statin in the Prevention of Post-CABG Atrial Fibrillation. Adv. Pharm. Bull. 2013, 4, 97-100. [PubMed]

(C) 2019 by the authors. Licensee MDPI, Basel, Switzerland. This article is an open access article distributed under the terms and conditions of the Creative Commons Attribution (CC BY) license (http://creativecommons.org/licenses/by/4.0/). 